\title{
Trade and Wages, Reconsidered
}

\begin{abstract}
Standard economic analysis predicts that increased U.S. trade with unskilled labor-abundant countries should reduce the relative wages of U.S. unskilled labor, but empirical studies in the 1990s found only a modest effect. Has the situation changed in this decade, given the surge in imports from very low wage countries? In fact, most of this increase has been in skillintensive goods such as computers, so that one would expect little additional impact on U.S. relative wages. However, developing countries appear to be specializing in unskilled labor-intensive niches within these industries. If so, the effect on wage inequality could still be significant. The paper develops a model and a numerical example showing that when developing countries can take over the unskilled labor-intensive portions of vertically specialized industries, the consequences can closely resemble the textbook effect. But determining the actual impact will require more finely disaggregated factor content data than are currently available.
\end{abstract}

\footnotetext{
7 here here has been a great transformation in the nature of world trade over the past three decades. Before the late 1970s, developing countries overwhelmingly exported primary products rather than manufactured goods; one relic of that era is that people still sometimes refer to wealthy nations as "industrial countries," when in fact industry currently accounts for almost twice as large a share of GDP in China as in the United States. Since then, however, developing countries have increasingly become major exporters of manufactured goods, and latterly of selected services as well.

From the beginning of this transformation it was apparent to international economists that the new pattern of trade might pose problems for low-wage workers in wealthy nations. Standard textbook analysis says that to the extent that trade is driven by international differences in factor abundance, the classic analysis of Wolfgang Stolper and Paul Samuelson, which shows that trade can have very strong effects on income
} 
Table 1. Selected Estimates of the Effect of Trade on Wages

\begin{tabular}{lcc}
\hline Study & $\begin{array}{c}\text { Effect of trade with developing0 } \\
\text { countries on skilled-unskilled } \\
\text { wage ratio (percentage points) }\end{array}$ & $\begin{array}{c}\text { Date of most } \\
\text { recent data }\end{array}$ \\
\hline Krugman (1995) & 3 & 1992 \\
Lawrence (1996) & 3 & 1993 \\
Cline (1997) & 7 & 1993 \\
Borjas, Freeman, and Katz (1997) & 1.4 & 1995 \\
\hline
\end{tabular}

Sources: Literature cited.

distribution, should apply. ${ }^{1}$ In particular, if trade with unskilled laborabundant countries leads to a reduction in the relative price of unskilled labor-intensive goods, this should, other things equal, reduce the real wages of less educated workers, both relative to other workers and in absolute terms. And in the 1980s, as the United States began to experience a marked rise in inequality, including a growing gap in wages between skilled and unskilled workers, it was natural to think that growing imports of unskilled labor-intensive goods from low-wage countries might be a major culprit.

But is the effect of trade on wages quantitatively important? A number of studies conducted during the 1990s concluded that the effects of NorthSouth trade on inequality were modest. Table 1 summarizes several wellknown estimates, together with one crucial aspect of each: the date of the latest data incorporated in the estimate.

For a variety of reasons, possibly including a reduction in concerns about wages during the economic boom of the later 1990s, the focus of discussion in international economics then shifted away from the distributional effects of trade in manufactured goods with developing countries. When concerns about trade began to make headlines again, they tended to focus on the new and novel aspects of trade-in particular the phenomenon of services outsourcing, which Alan Blinder, in a much-quoted popular article, ${ }^{2}$ went so far as to call part of a new Industrial Revolution.

Until recently, however, surprisingly little attention was given to how increasingly out of date the data are behind the reassuring consensus that trade has only modest effects on income distribution. Yet the problem is obvious and was in fact noted by Federal Reserve chairman Ben Bernanke last year: "Unfortunately, much of the available empirical research on the influence of trade on earnings inequality dates from the 1980s and 1990s

1. Stolper and Samuelson (1941).

2. Blinder (2006). 
Figure 1. Imports of Manufactures from Developed and Developing Countries, 1989-2006

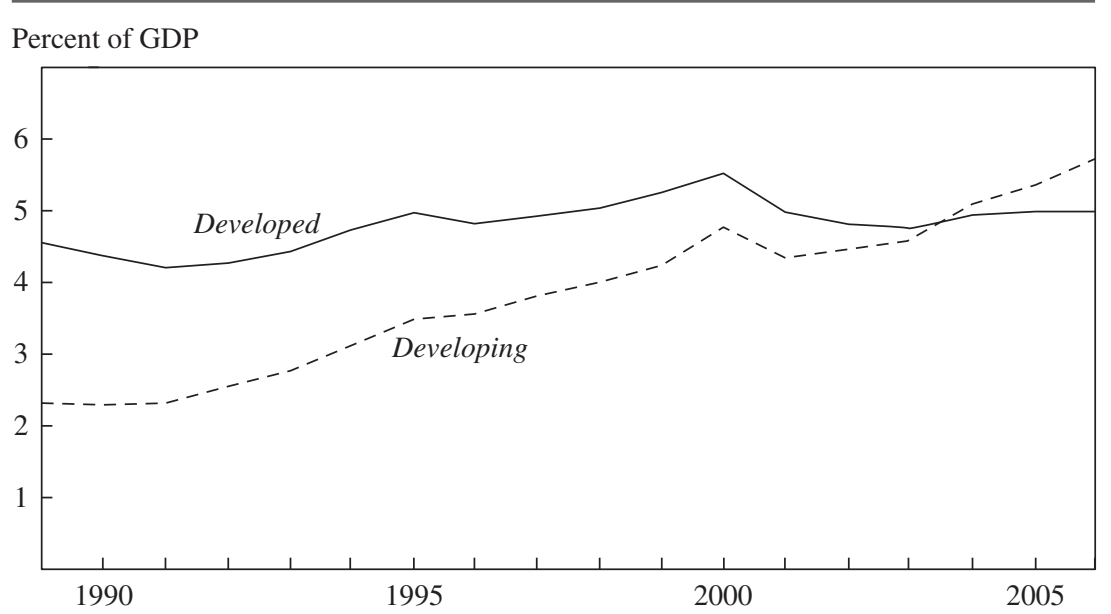

Sources: U.S. International Trade Commission DataWeb and author's calculations.

and thus does not address later developments. ${ }^{33}$ And there have been a lot of later developments.

Figure 1 shows U.S. imports of manufactured goods as a percentage of GDP since 1989, split between imports from developing countries and imports from developed countries. ${ }^{4}$ It turns out that developing country imports have roughly doubled as a share of the U.S. economy since the studies that concluded that the effect of trade on income inequality was modest. This seems, at first glance, to suggest that estimates of this effect should be scaled up accordingly. Josh Bivens has done just that with the simple model I offered in my 1995 Brookings Paper, concluding that the distributional effects of trade are now much larger. ${ }^{5}$

There is another aspect to the change in trade: the developing countries that account for most of the expansion in trade since the early 1990s have substantially lower average wages, relative to wages in developed countries, than the developing countries that were the main focus of concern in

3. Bernanke (2007).

4. Throughout this paper, manufactured goods are defined using the North American Industry Classification System (NAICS). "Developed countries" are defined as all members of the Organization for Economic Cooperation and Development except Korea, Mexico, and Turkey; all others are developing countries.

5. Bivens (2007); Krugman (1995). 
the original literature. In particular, China's average hourly compensation in manufacturing is estimated by the Bureau of Labor Statistics (BLS) to be only 3 percent of the U.S. level at the current exchange rate. ${ }^{6}$ Again, this shift to lower-wage sources of imports seems to suggest that the distributional effects of trade may well be considerably larger now than they were in the early 1990s.

But should one jump to the conclusion that although the effects of trade on distribution were not serious then, they are now? It turns out that there is a problem: although the aggregate picture suggests that the distributional effects of trade should have gotten substantially larger, detailed calculations of the factor content of trade-which played a key role in some earlier analyses-do not seem to support that conclusion. This result, in turn, rests on what appears in the data to be a marked increase in the sophistication of the goods the United States imports from developing countriesin particular, a sharp increase in imports of computers and electronic products compared with traditional unskilled labor-intensive goods such as apparel.

Robert Lawrence, in a recent study that shares the same motivation as this paper, essentially concludes from the evidence on factor content and the apparently rising sophistication of developing country imports that the rapid growth of these imports has not, in fact, been a source of rising inequality. ${ }^{7}$ But this conclusion is, in my view, too quick to dismiss what seems like an important paradox. On one side, the United States and other developed countries have seen a surge in imports from countries that are substantially poorer and more abundant in unskilled labor than the developing country exporters that created so much anxiety a dozen years ago. On the other side, the United States seems to be importing goods that are more skilled labor intensive and less unskilled labor intensive than before. As I will show, the most important source of this paradox lies in the information technology sector: for the most part there remains a clear tendency for developing countries to export unskilled labor-intensive products, but the large exports of computers and electronics from the developing world stand out as a clear anomaly.

One possible resolution of this seeming paradox is to argue that the data on which factor content estimates are based suffer from severe aggregation problems - that developing countries are specializing in unskilled labor-

6. Bureau of Labor Statistics (2006).

7. Lawrence (2008). 
intensive niches within otherwise skilled labor-intensive sectors, especially in computers and electronics. I will make that case later in the paper, while admitting that the evidence is fragmentary. If this is the correct interpretation, however, the effect of rapid trade growth on wage inequality may indeed have been significant.

Just to be clear: even if growing trade has in fact had significant distributional effects, that is a long way from saying that calls for import protection are justified. First of all, although supporting the real wages of less educated U.S. workers should be $a$ goal of policy, it is not the goal: for example, sustaining a world trading system that permits development by very poor countries is also an important policy consideration. Second, as generations of economists have argued, the first-best response to the adverse distributional effects of trade is to compensate the losers, rather than to restrict trade. Yet whether trade is, in fact, having significant distributional effects, rather than being an all-round good thing, clearly matters.

The remainder of this paper is in four parts. The first part offers an overview of the changes in U.S. trade with developing countries, in a way that sets the stage for the later puzzle. The second part describes the theoretical basis for analyzing the distributional effects of trade, and then shows how calculations at the aggregate level and factor content analysis yield divergent conclusions. The third part turns to the case for aggregation problems and the implications of vertical specialization within industries. The final part considers the implications both for further research and for policy.

\section{The Changing Pattern of Trade}

Figure 1 showed the dramatic rise in U.S. imports of manufactured goods from developing countries since 1989. One qualification that needs to be made right away is that to some extent this rise reflects the movement of the United States into massive trade deficit. The theoretical analysis later in this paper suggests that the average of imports and exports may be a better guide to the likely distributional effects than imports alone. Figure 2 shows this average as a percentage of GDP for U.S. trade in manufactured goods with developing and developed countries; the rise in developing country trade is slightly less dramatic, but still impressive. Figure 2 also shows that 2006 marked a watershed: in that year, for the first time, the United States began doing more total trade in manufactured goods with developing countries than with other developed countries.

This rapid growth in U.S. trade with developing countries mainly took the form of increased trade with countries that were only minor players in 
Figure 2. Average of Imports and Exports of Manufactures from Developed and Developing Countries, 1989-2006

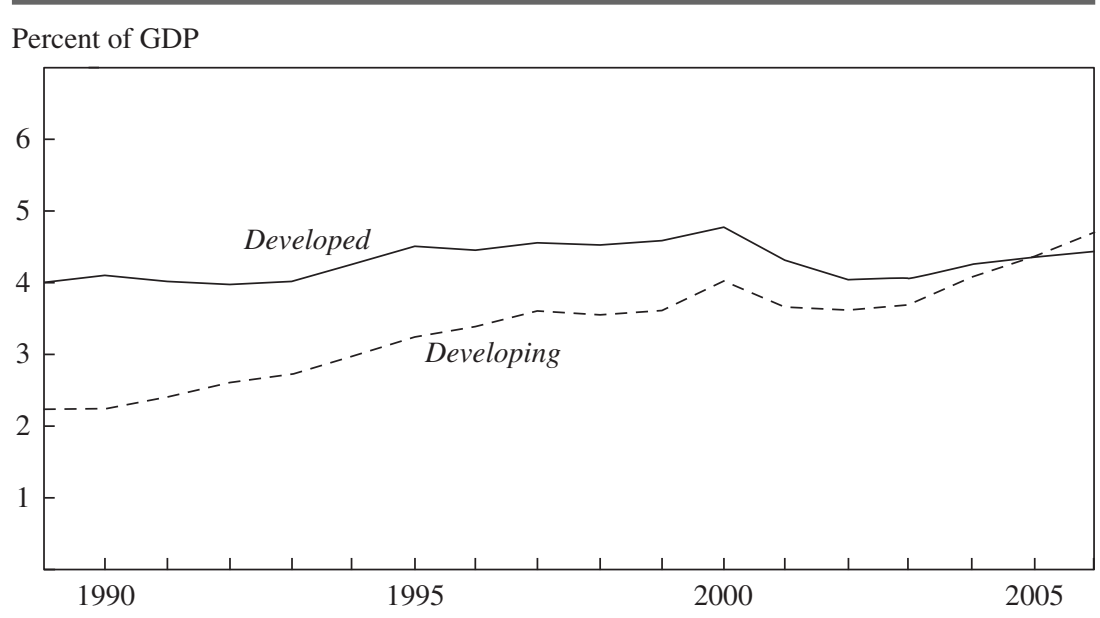

Sources: U.S. International Trade Commission DataWeb and author's calculations.

the early 1990s. At the time of the earlier literature on trade and income distribution, North-South trade in manufactures still, to a large extent, involved the original four Asian "tigers": Hong Kong, Singapore, South Korea, and Taiwan. Since then, however, growth in U.S. trade with developing countries has principally involved China, Mexico, and some smaller players. Figure 3 is an area chart of U.S. manufactured imports from developing countries, again as a percentage of GDP; it shows a modest relative decline for the original tigers and a large rise for Mexico and especially China.

This changing direction of North-South trade has one immediate implication: the countries where growth in trade is occurring today have even lower average wages than those where the growth was occurring in the early 1990s. Thus, the aspect of this trade that initially attracted so much (often hostile) attention has, from the critics' perspective, only gotten worse. In 1990, according to BLS estimates, average hourly compensation in manufacturing in the four tigers was 25 percent of the U.S. level, and by 1995 that figure had risen to 39 percent. But as of 2005 the BLS estimated that hourly compensation in Mexico was only 11 percent of the U.S. level, and in China, as already mentioned, it was slightly more than 3 percent.

As a result, one trend often cited in the early 1990s as a reason to discount fears about the effect of trade on wages - the rise in the average wage of U.S. trading partners relative to the U.S. level-has gone into reverse. 
Figure 3. Country Composition of Manufactures Imports from Developing Countries, 1989-2006

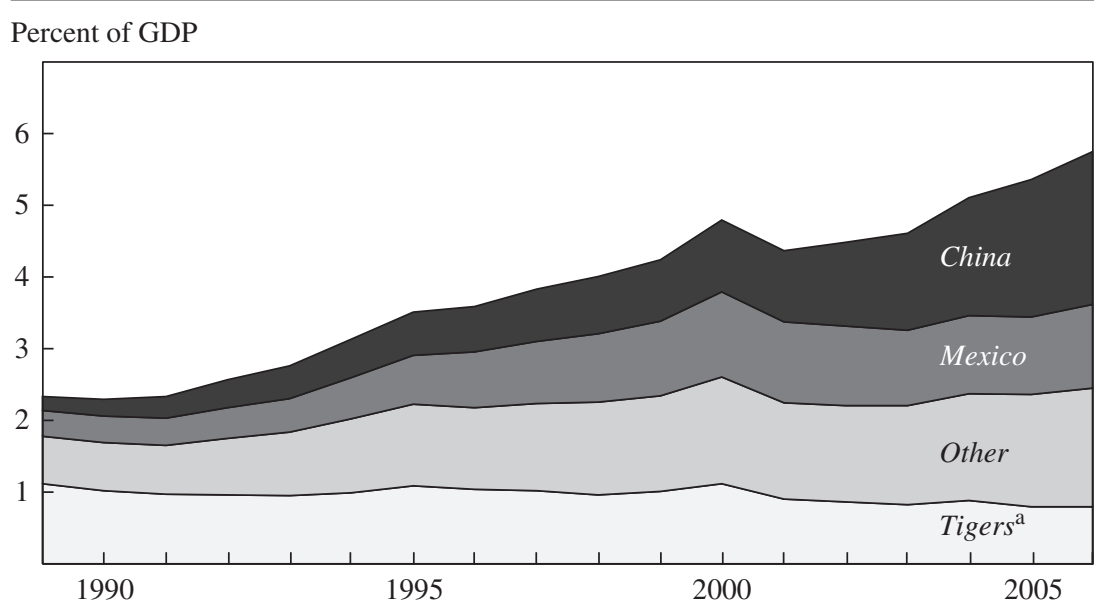

Sources: U.S. International Trade Commission DataWeb and author's calculations. a. Hong Kong, Singapore, South Korea, and Taiwan.

Table 2 lists the top ten U.S. trading partners and the average hourly compensation of manufacturing workers in those countries, weighted by the value of bilateral trade and expressed as a percentage of the U.S. level, since 1975. This measure did indeed rise from 1975 to 1990, reflecting rising relative wages both in developed country trading partners and in the original Asian tiger economies. Since 1990, however, the rapidly rising

Table 2. Average Hourly Compensation in the Top Ten U.S. Trading Partners, 1975, 1990 , and 2005

\begin{tabular}{|c|c|c|}
\hline Year & Top ten trading partners (largest first) & $\begin{array}{l}\text { Average hourly compensation } \\
\quad(\text { percent of U.S. average })^{\mathrm{a}}\end{array}$ \\
\hline 1975 & $\begin{array}{l}\text { Canada, Japan, Germany, United Kingdom, } \\
\text { Mexico, France, Italy, Brazil, } \\
\text { the Netherlands, Belgium }\end{array}$ & 76 \\
\hline 1990 & $\begin{array}{l}\text { Canada, Japan, Mexico, Germany, } \\
\text { United Kingdom, Taiwan, South Korea, } \\
\text { France, Italy, China }\end{array}$ & $81^{\mathrm{b}}$ \\
\hline 2005 & $\begin{array}{l}\text { Canada, Mexico, China, Japan, Germany, } \\
\text { United Kingdom, South Korea, Taiwan, } \\
\text { France, Malaysia }\end{array}$ & $65^{\mathrm{c}}$ \\
\hline
\end{tabular}

Sources: Bureau of Labor Statistics (2006); Statistical Abstract of the United States.
a. Averages are weighted by the countries' shares in total U.S. trade.
b. China's hourly compensation is assumed to be 1 percent of the U.S. level.
c. Malaysia's hourly compensation is estimated from United Nations data. 
Table 3. China and Mexico: GDP and Manufactured Exports to the United States, 1990 and 2006

\begin{tabular}{|c|c|c|c|}
\hline \multirow[b]{2}{*}{ Country and measure } & \multicolumn{2}{|c|}{ Percent of U.S. GDP } & \multirow{2}{*}{$\begin{array}{l}\text { Change, } \\
\text { 1990-2006 } \\
\text { (percent) }\end{array}$} \\
\hline & 1990 & 2006 & \\
\hline \multicolumn{4}{|l|}{ China } \\
\hline GDP & 6.7 & 20.0 & 199 \\
\hline Manufactured exports & 0.24 & 2.13 & 788 \\
\hline \multicolumn{4}{|l|}{ Mexico } \\
\hline GDP & 4.6 & 6.4 & 39 \\
\hline Manufactured exports & 0.37 & 1.16 & 214 \\
\hline
\end{tabular}

Sources: U.S. International Trade Commission DataWeb; International Monetary Fund, World Economic Outlook database.

weight of China and, to a lesser extent, Mexico has driven the index down by approximately 20 percent. $^{8}$

What accounts for the rapid growth of manufactured imports from these new players? China's economy, at least, has grown very rapidly, and one might imagine that the growth of China's exports simply reflects that. Simple gravity models, in which trade between any pair of countries reflects the product of their GDPs, adjusted for the distance between them, generally work quite well and have become a standard tool for interpreting the overall pattern of trade. Such a model would lead one to expect U.S. imports from China as a percentage of GDP to have risen, other things equal, in proportion to the ratio of Chinese to U.S. GDP.

In fact, however, U.S. imports from China have risen much more rapidly than the growth of the Chinese economy, on its own, would have led one to expect. Table 3 compares the growth in Chinese and Mexican GDP with growth in imports from each country, both as a percentage of U.S. GDP. Chinese GDP, at market exchange rates, has tripled relative to U.S. GDP, but U.S. imports of manufactured goods from China have increased almost eightfold as a percentage of GDP. Mexico's GDP as a percentage of U.S.

8. The most commonly used measure of the relative wages of U.S. trading partners, from the BLS (2006), gives a somewhat different picture from that in table 2: it shows a more rapid rise between 1975 and 1990, from 62 percent to 80 percent of the U.S. level, and essentially no change from 1990 to 2005 . However, the BLS measure is fixed-weighted: hourly compensation in each country is weighted by 2004 trade with the United States. As a result, the BLS index does not reflect the recent shift in U.S. manufactures trade to developing countries. 
GDP has risen about 40 percent, but Mexico's manufactured exports to the United States have tripled relative to U.S. GDP.

The obvious explanation of this "excess growth" in manufactured exports is that it reflects reduced barriers to trade, which have led to greater international specialization and hence greater trade. In the case of Mexico, it is natural to suppose that NAFTA has played an important role, although much of the growth in Mexican exports may also reflect two other factors: the delayed effects of Mexico's dramatic unilateral liberalization of trade between 1985 and 1988, and the weak peso that followed the 1994-95 financial crisis.

In the case of China, there is no comparable break in policy. However, work by David Hummels, Jun Ishii, and Kei-Mu Yi suggests that even modest declines in trade costs can lead to large increases in the volume of trade by encouraging vertical specialization - the breakup of the production process into geographically separate stages. ${ }^{9}$ Thus rapid growth in Chinese exports might reflect declines in the cost of international communication and shipping.

One piece of evidence that may support the view that rapid growth in imports from developing countries reflects declining trade costs, both explicit and implicit, is the changing composition of these imports. A quick way to see the extent of this change in composition is to rely on a distinction introduced by Jason Faberman. ${ }^{10}$ In analyzing job losses and gains, Faberman distinguishes a group of "trade-sensitive" industries (at the NAICS three-digit level) with very large import shares that also corresponds quite well to goods traditionally exported by developing countries. Figure 4 shows the long-term trend in U.S. imports of manufactured goods from developing countries as a percentage of GDP, divided between "tradesensitive" and other goods. Even in 1989, it turns out, traditional developing country manufactured exports accounted for less than half of all U.S. imports from developing countries. More to the point, however, the bulk of the growth in imports since then has come from nontraditional sectors.

What are these nontraditional goods? Figure 5 shows the change over the same period in imports from developing countries as a percentage of U.S. GDP by three-digit NAICS sector, from largest to smallest. What is striking here, of course, is the extraordinary growth in imports of computers and electronics.

9. Hummels, Ishii, and Yi (2001).

10. Faberman (2004). 
Figure 4. "Trade-Sensitive” Imports from Developing Countries, 1989-2006

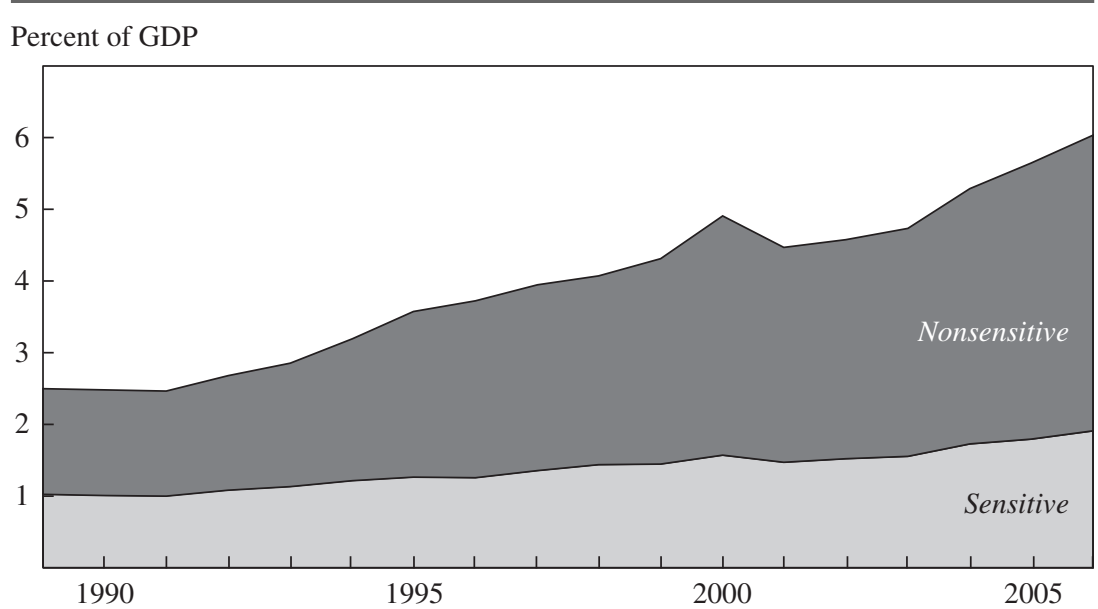

Sources: U.S. International Trade Commission DataWeb and author's calculations. a. "Trade-sensitive" industries are as defined by Faberman (2004).

\section{Modeling the Effects of Trade on Income Distribution}

There have been two major waves of innovation in international trade theory over the roughly thirty years since developing country exports of manufactured goods began to be a significant concern: the increasing-returns, imperfect-competition revolution of the 1980s, and the more recent focus on interfirm differences in productivity and propensity to export within industries. It is not clear, however, how to apply the insights of either set of ideas to the question of the distributional effects of developing country exports. As a result, most analysis of this issue continues to rely on the simple factor proportions model assuming perfect competition.

The first key insight from this model is the Stolper-Samuelson relationship between goods prices and factor prices. Consider a world in which there are two factors of production, skilled labor and unskilled labor, and two goods produced competitively under constant returns to scale, a skilled labor-intensive good X and an unskilled labor-intensive good Y. Assume that workers move freely between firms and industries, so that all workers of each type receive the same wage. Finally, assume provisionally that an economy produces both goods. Then there is a one-to-one relationship between the relative prices $P$ of the two goods and the relative wages $w$ of the two types of labor. Letting a "hat" represent proportional rates of change, 
Figure 5. Growth in Manufacturing Imports by Industry, 1989-2006

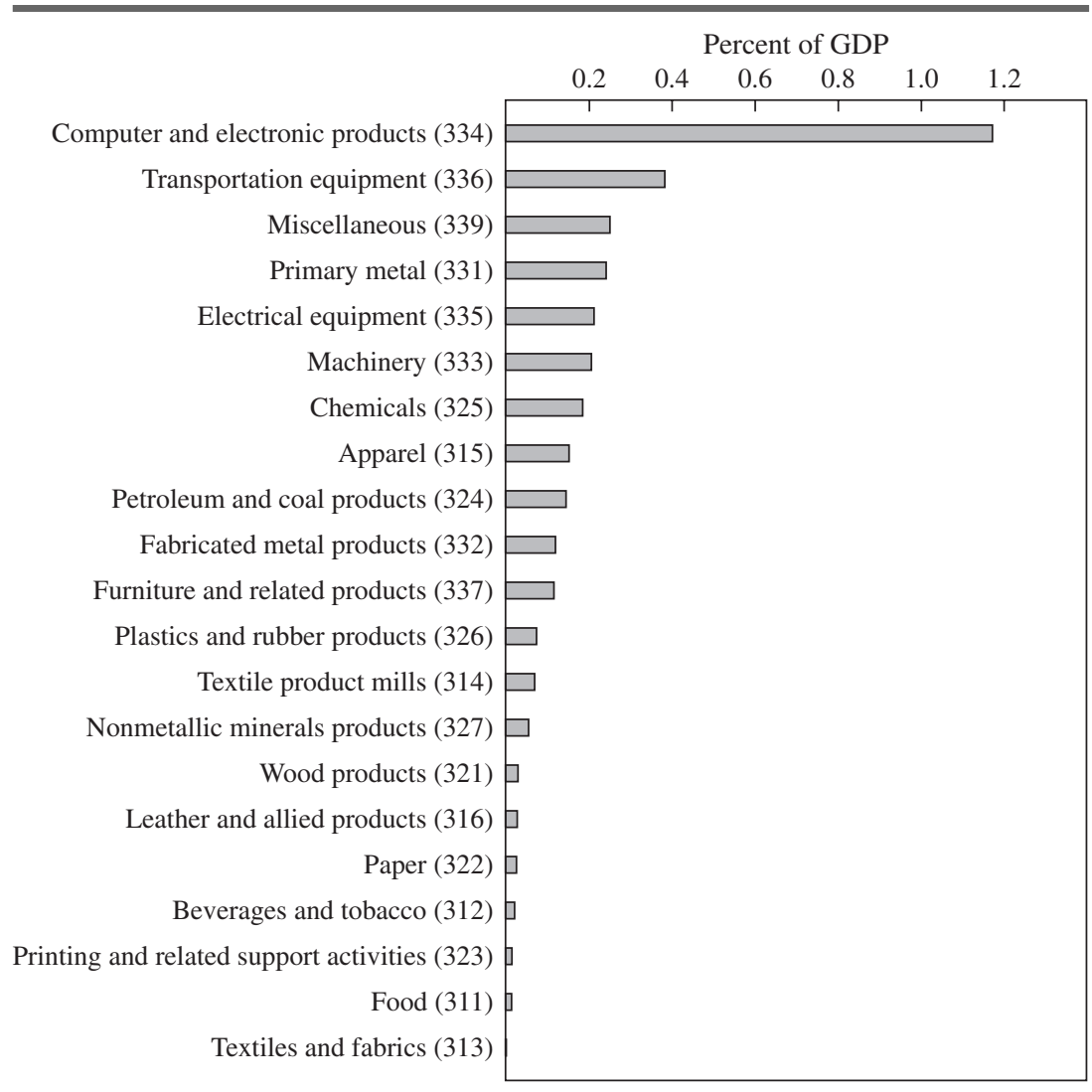

Sources: U.S. International Trade Commission DataWeb and author's calculations.

$$
\hat{P}_{X}-\hat{P}_{Y}=\left(\theta_{S X}-\theta_{S Y}\right)\left(\hat{w}_{S}-\hat{w}_{U}\right),
$$

where $\theta_{S X}$ and $\theta_{S Y}$ are the shares of skilled labor in the production cost of $\mathrm{X}$ and $\mathrm{Y}$, respectively.

Figure 6 completes the story. The left panel shows the relationship between relative goods prices and relative factor prices. The right panel shows the relationship between factor prices and the ratio of skilled to unskilled labor used in production. In each industry a rise in the relative wage of skilled workers leads to a fall in the ratio of skilled to unskilled workers. This is one way to see the logic behind the Stolper-Samuelson result. As long as the country continues to produce both goods, a rise in the relative price of the skilled labor-intensive good must lead to a rise in the 
Figure 6. Wages, Prices, and the Skilled-Unskilled Labor Ratio

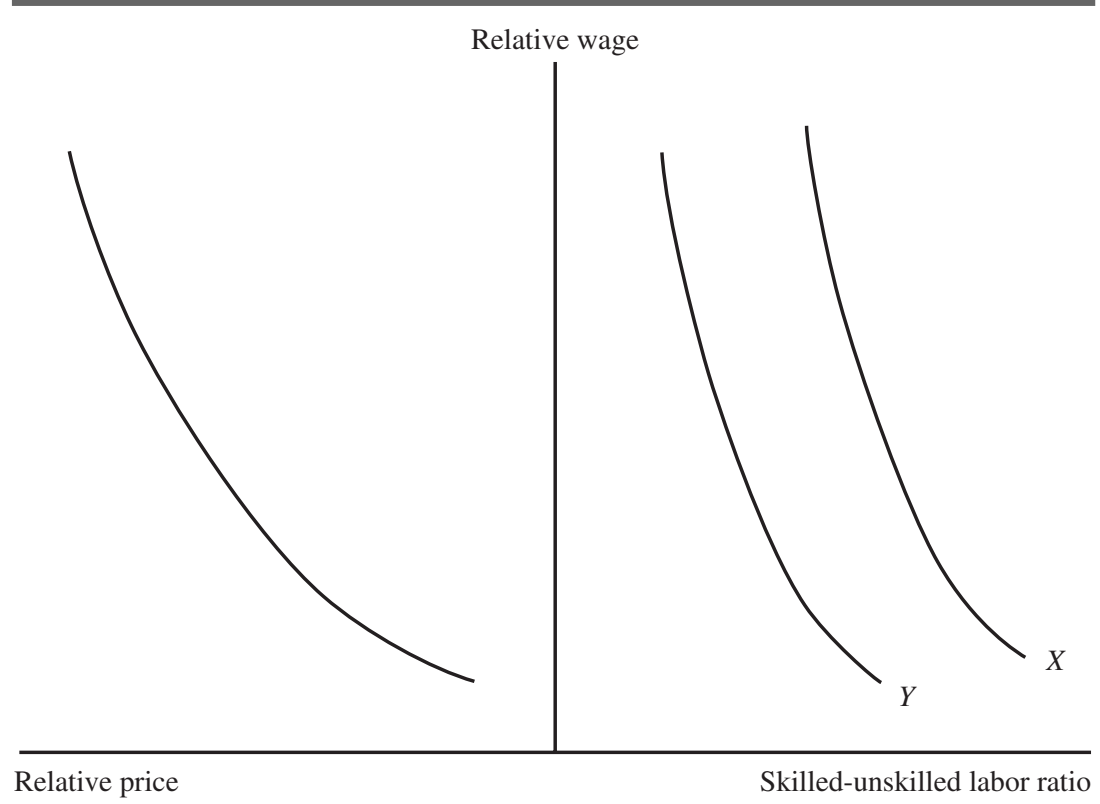

Source: Krugman (1995).

relative wages of skilled workers. This implies a fall in the ratio of skilled to unskilled workers in both industries - and hence a fall in the marginal productivity of unskilled workers in terms of both goods. And that, in turn, means that the real wage of unskilled workers unambiguously falls.

One more point about this analysis is worth noting: the Stolper-Samuelson process involves a complex reshuffling of resources between industries. Consider what happens, according to this model, if the relative price of $\mathrm{X}$ rises. Production within each industry becomes less skill intensive, yet total employment of both factors remains unchanged because the industrial mix of production shifts toward skill-intensive industries. This is not a process one should expect to play out in full in the short run; the moral I would take from this is that the Stolper-Samuelson theorem should not be taken too seriously when interpreting data over short periods, say, five years.

But the focus of this paper is on a somewhat longer period-the years since the early 1990s, whose data were the basis for the relatively benign estimates of the effect of trade on wages that still dominate discussion. Are the data since then consistent with a strong Stolper-Samuelson effect? At first glance, the answer appears to be yes. 
Figure 7. Relative Prices of Developing and Developed Country Manufactures, $1990-2007^{\mathrm{a}}$

Log points $(1995=0)$

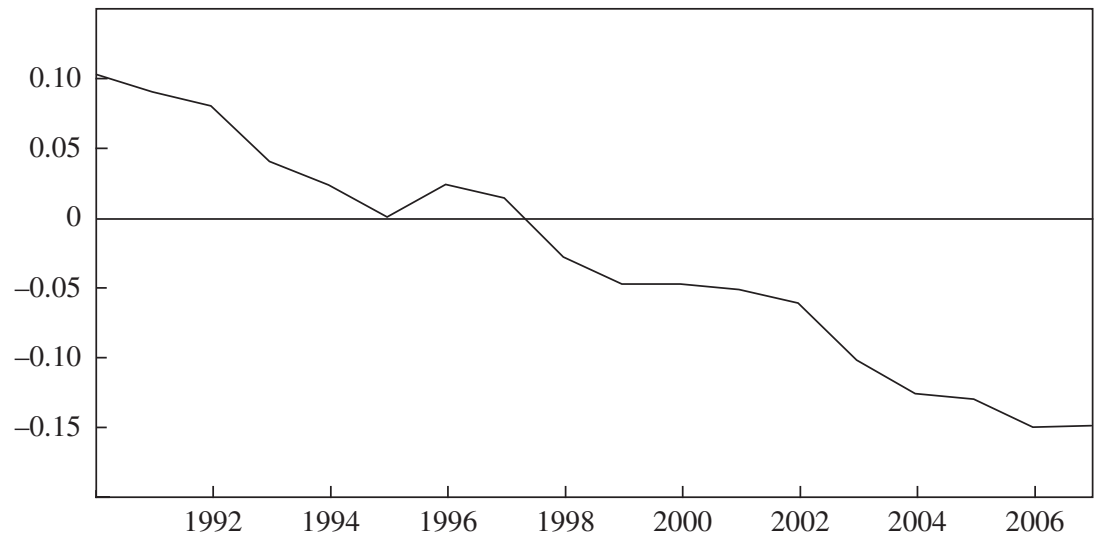

Sources: Bureau of Labor Statistics and author's calculations.

a. Log of the ratio of the average price of developing country manufactures to that of developed country manufactures.

Consider first how prices have changed. The BLS publishes price indices of manufactured imports from developing and developed countries. If it is assumed that developing countries mainly export unskilled labor-intensive goods to the United States whereas developed countries export skilled labor-intensive goods (an assumption to be confirmed, with a major asterisk - the case of computers and electronics-in the next section), the ratio of these prices should offer a measure of the relative price of unskilled labor-intensive goods. Figure 7 shows the logarithm of this ratio, normalized so that $1995=0$. There indeed seems to have been a substantial decline in the relative price of unskilled labor-intensive goods since the mid-1990s.

Consider next changes in relative wages. Figure 8 shows two widely used indicators of wage differentials: the 90-50 ratio of hourly wages and the college-noncollege ratio. Both are shown for men only, to abstract from changes in sex differentials; both are also expressed in logarithms, normalized so that $1995=0$. Both measures have risen substantially since 1995 .

Lawrence, however, reaches a different conclusion, arguing that trends in relative wages are not consistent with a trade-driven story. ${ }^{11}$ This difference in interpretation arises, I believe, from two factors. First, Lawrence 
Figure 8. Hourly Wage Differentials for Males, 1973-2005

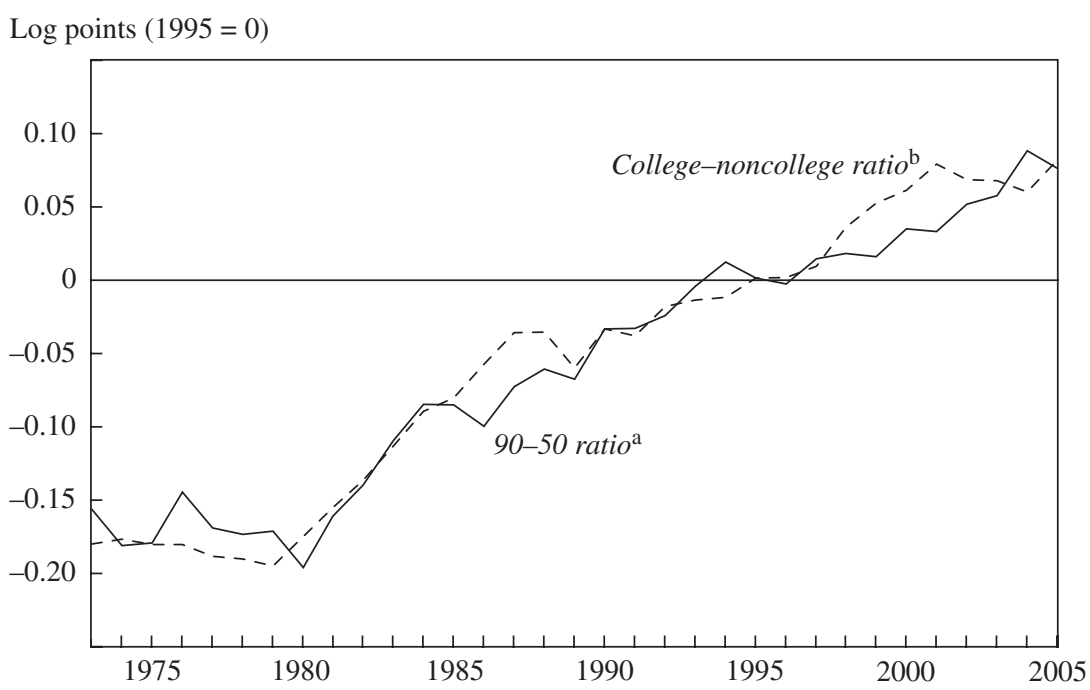

Sources: Bureau of Labor Statistics and author's calculations.

a. Log of the ratio of wages at the 90th percentile of the wage distribution to wages at the median.

b. Log of the ratio of average wages earned by college graduates to those of non-college graduates.

uses earnings data aggregated across sexes, which do not show as strong a rise in inequality as the male-only data. (Goldin and Katz, using fixed weights by sex and age, find a continuing rise in both college-noncollege and 90-50 inequality. ${ }^{12}$ ) Second, he focuses primarily on the period since 2000 rather than the longer stretch since the mid-1990s.

I would argue that this short-term focus is problematic in two respects. First, on general principles it is not clear what one learns from very short term movements in relative wages. As argued above, the adjustment implied by the Stolper-Samuelson theorem involves a complex reallocation of resources across industries, making it unsuitable for short-term analysis. Second, and more specifically, the period since 1995 includes a major boom-bust cycle in high-technology industries. The technology bubble of the late 1990s probably elevated the education premium, and the subsequent bust caused that premium to deflate. As a result, inferences from the movement in inequality during the first few years after the technology bust should be taken with a grain of salt. Perhaps the more general point is that

12. Goldin and Katz (2007). 
Stolper-Samuelson is a ceteris paribus proposition and as such cannot be refuted - or, to be sure, confirmed — from the movement of relative wages alone.

That said, the combination of the price changes shown in figure 7 and the wage changes shown in figure 8 does look reasonably supportive of the proposition that rapid growth in North-South trade since the studies of the mid-1990s has made the effects on inequality substantially larger. There is, however, a big problem with that conclusion: when one uses the methods I and others applied to the subject of trade and wages in the 1990s to more recent data, the results do not, at least on first appearances, fit the story.

There was a fairly heated dispute in the 1990s over the appropriate way to analyze the effects of North-South trade on wages. Some economists, notably Edward Leamer, ${ }^{13}$ argued that since the relationship shown in figure 6 is between goods prices and factor prices, the only legitimate approach is to rely on price information, rather than on the volume of trade, which is endogenous. Others, myself included, argued that this represented a confusion between the question of how best to present models and the question of how to construct the appropriate thought experiment for analysis: it makes sense to present Stolper-Samuelson as a goods-price, factor-price relationship, but in the real world prices are as endogenous as trade volumes. The appropriate method, I argued, ${ }^{14}$ was "but for" analysis: compare goods and factor prices with an estimate of what they would have been but for the opportunity to engage in manufactures trade with developing countries. And this but-for analysis inevitably leans strongly on calculations involving trade volumes.

Figure 9 illustrates that thought experiment from my 1995 paper. As in figure 6, I assume that there are two goods, one skilled labor intensive, one unskilled labor intensive. The curve PPF represents the production possibilities of the developed world in the aggregate. If it were not possible to trade skilled labor-intensive goods for unskilled labor-intensive imports from developing countries - that is, but for the possibility of North-South trade-equilibrium would be at the autarkic point A. In fact, however, this possibility exists; the opportunities for trade with newly industrializing economies are represented by the offer curve NIEO. As a result, equilibrium production is at $\mathrm{Q}$, and equilibrium consumption is at $\mathrm{C}$, with the line $\mathrm{PP}$ representing relative prices in trade. The relative price of skilled laborintensive goods is higher, and that of unskilled labor-intensive goods

13. Leamer (1994).

14. Krugman (1995). 
Figure 9. Effect of Trade on Prices of Skilled and Unskilled Labor

Unskilled labor-intensive goods

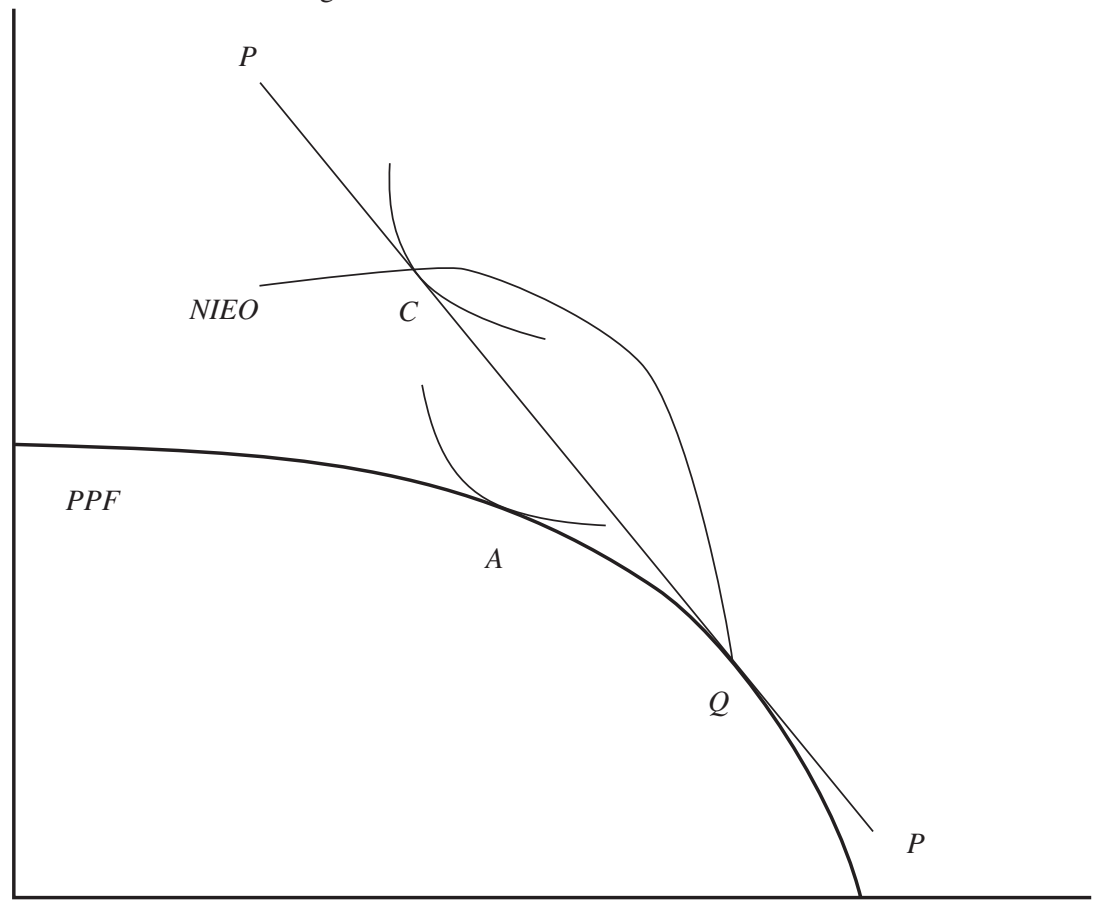

Skilled labor-intensive goods

Source: Krugman (1995).

lower, than would obtain in the absence of trade. Hence the StolperSamuelson effect applies.

In the original analysis I created an extremely simple computable general equilibrium model to calculate a back-of-the-envelope estimate of this but-for effect. This appears at first sight to be a significantly different approach from analyses such as that of George Borjas, Richard Freeman, and Lawrence Katz, ${ }^{15}$ who instead try to calculate the factor content of trade - the factors of production embodied in imports and exports. However, in my later work, ${ }^{16}$ it became apparent that the factor content approach, interpreted carefully, is fully consistent with an analysis based on trade flows and their effect on relative prices.

15. Borjas, Freeman, and Katz (1997).

16. Krugman $(1996,2000)$. 
Figure 10. Effect of Replacing Trade with Equivalent Factor Endowment

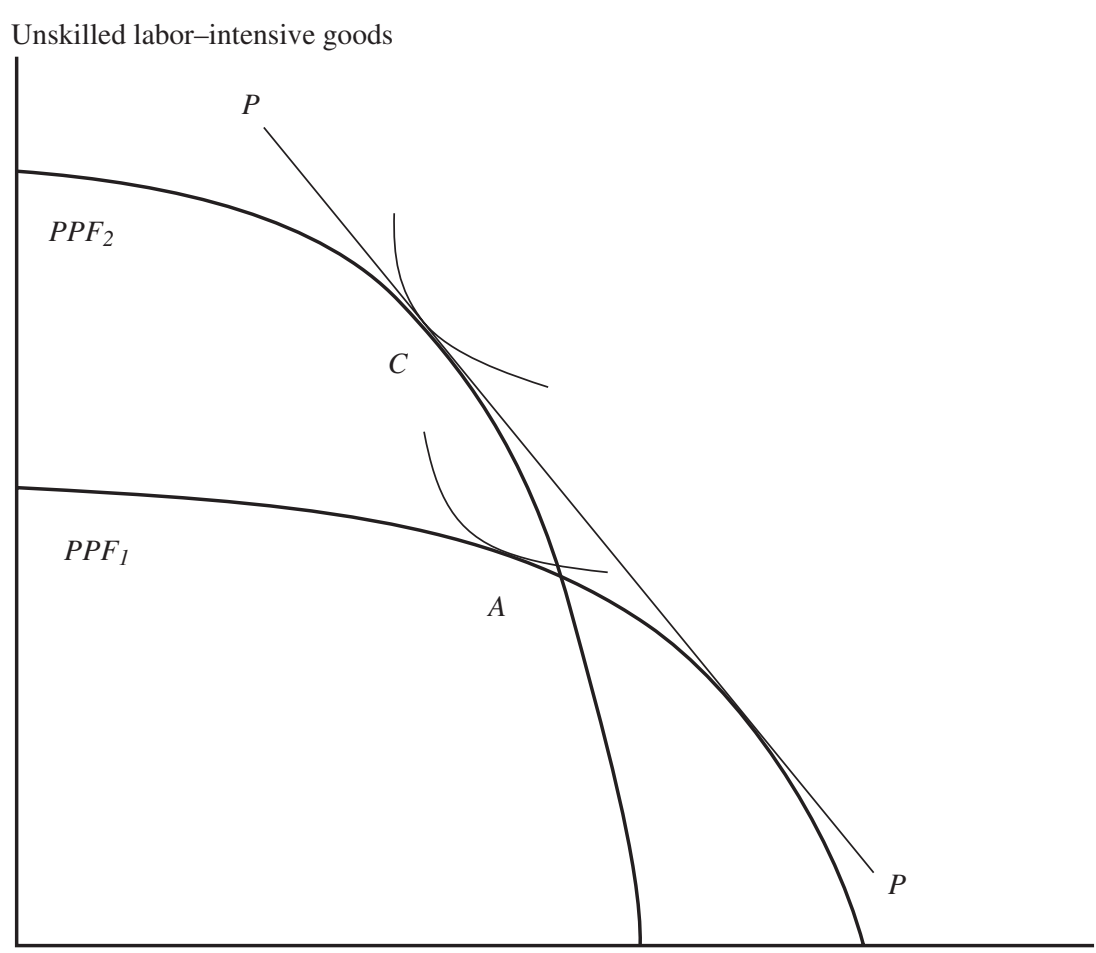

Skilled labor-intensive goods

Source: Author's model described in the text.

Figure 10 shows how this reconciliation can be carried out. Imagine holding goods prices constant while altering the economy's factor endowment, subtracting skilled labor while adding unskilled labor. This would have the effect of shifting the production possibility frontier inward at the lower right, but upward at the upper left, as illustrated by the shift from the production possibility frontier $\mathrm{PPF}_{1}$ to $\mathrm{PPF}_{2}$. Production would also shift, at constant goods prices, toward less output of the skilled labor-intensive good and more of the unskilled labor-intensive good. More specifically, suppose that at the initial factor prices the value of factors added is equal to the value of factors subtracted. Then production would shift northwest up the relative price line PP. If the change in factor endowments is sufficiently large, production will reach point $\mathrm{C}$; that is, production will match consumption, so that trade is eliminated. And what is this change in factor endowments? It is precisely equal to the factor content of the initial 
volume of trade, as measured using the factor content of each good's production per dollar of value in the developed economy (not in the developing economy) under the actual trading regime.

Now, having added the factor content of trade to the developed economy, thereby eliminating the need for actual trade, imagine a further thought experiment in which, first, the possibility of trade is eliminated, and then the change in factor endowments is reversed. This would shift the production possibility frontier back to $\mathrm{PPF}_{1}$, but because trade is no longer possible, consumption, production, and relative prices would end up at the original autarky point A.

This may seem rather roundabout, but what it says is the following: the but-for thought experiment of eliminating North-South trade has the same effect on wages as another thought experiment that takes a nontrading economy whose resources include the actual economy's factor endowment plus the factor content of the actual economy's trade, and then eliminates that difference in factor endowments. In this sense, then, the factor content approach, carefully interpreted, is equivalent to the but-for trade analysis.

There are two advantages to thinking about the issue in terms of factor content. One is that it simplifies the interpretation of any structural model. In general, the results of any such model depend on all the parameters: factor shares in production, goods shares in spending, and all the relevant elasticities of substitution in both production and consumption. However, thinking in terms of factor content makes it clear that these parameters matter only insofar as they affect one derived number, the aggregate elasticity of substitution between skilled and unskilled labor. This simplifies sensitivity analysis and in general helps clarify interpretation. ${ }^{17}$

The other advantage of thinking in terms of factor content is that it simplifies the task of empirical work - or at least it seemed to do so in the past. Rather than having to calibrate a full model, the researcher can simply estimate the factor content of trade, which is informative in itself, and assess likely impacts by examining the implications of alternative aggregate elasticities of substitution.

All of this assumes that one can do a reasonably good job of measuring factor content. Before attempting that, however, it is useful to extend the analysis to allow for an important feature of U.S. trade, especially recently: large trade deficits.

17. Note, however, that the relevant elasticity of substitution between factors is the one that would prevail in the absence of trade. So it is somewhat problematic to rely, as for example Borjas, Freeman, and Katz (1997) do, on estimates of this elasticity from time series that include a period of significant trade. 
Figures 9 and 10 are real-trade theory diagrams, assuming, as must be the case under standard real-trade models, that trade is balanced. Clearly that is not a reasonable assumption for the United States today, which runs large trade deficits financed by capital inflows. (Around 2005 a rough description of the U.S. economy would have been that Americans made a living selling each other houses, paying for them with money borrowed from China.) However, it is possible to use the factor content approach under conditions of trade deficit by making two further assumptions. The first is that the effects of capital inflows on demand are equivalent to a transfer payment to domestic households. (That is, capital inflows are spent in the same way as domestically earned income.) The second is that all domestic consumers have identical homothetic preferences, so that the composition of spending does not depend on who is receiving income.

Under these assumptions the factor content exercise can be represented by figure 11 . Here the economy's actual production and consumption are once again at $\mathrm{Q}$ and $\mathrm{C}$, but this time the value of consumption at world prices $\mathrm{PP}$ exceeds that of production. The difference is the trade deficit, represented as a transfer of income to domestic consumers. Again, it is possible to construct a hypothetical economy that would produce the actual economy's consumption without the need for trade; this can be done by adding the actual factor content of trade to the original economy, which shifts the production possibility frontier from $\mathrm{PPF}_{1}$ to $\mathrm{PPF}_{2}$. The effect of trade on factor prices can then be inferred by subtracting the factor content of trade out again. Because of the assumption of homothetic preferences, the effect on relative factor prices depends on the extent to which the ratio of factors is altered in this exercise. In particular, even if a country runs so large a trade deficit that it is implicitly an importer of both skilled and unskilled labor, trade still raises the skill premium as long as constructing the hypothetical no-trade economy requires increasing the quantity of unskilled labor by more, in percentage terms, than the quantity of skilled labor.

And now we get to the fundamental empirical puzzle. In the early to mid-1990s, factor content exercises indicated a significant, if modest, move in the expected direction. The most recent estimates, however, suggest that the dramatic expansion of imports from low-wage countries since 1990 has not significantly enlarged the factor content of trade.

Table 4 reports estimates of "job displacement" by education levelanother name for factor content-from Lawrence Mishel, Jared Bernstein, and Sylvia Allegretto. ${ }^{18}$ The estimates were constructed using changes in

18. Mishel, Bernstein, and Allegretto (2006). 
Figure 11. Effect of Trade on Skilled and Unskilled Wages with a Trade Deficit

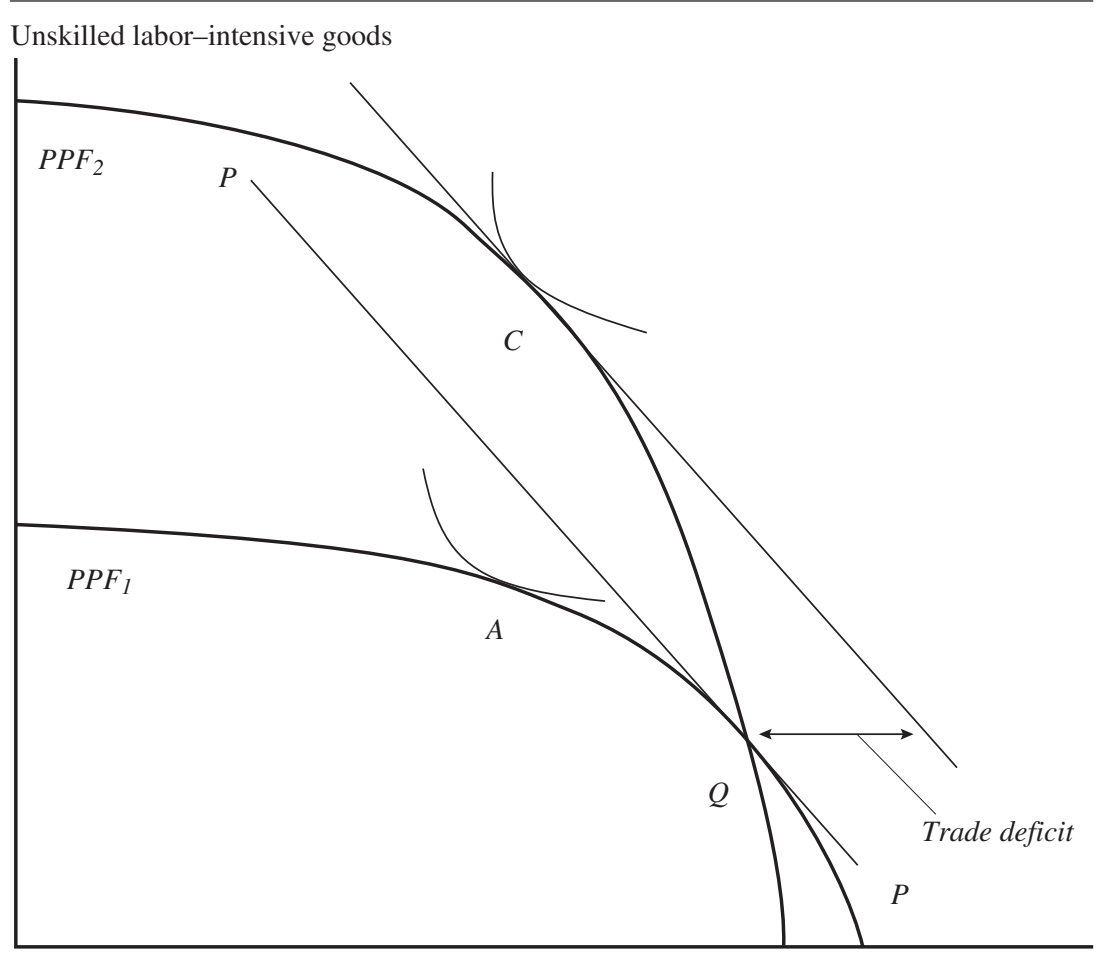

Skilled labor-intensive goods

Source: Author's model described in the text.

the ratios of imports and exports to total sales within each four-digit NAICS industry to estimate changes in sales due to trade; these estimates were then run through the input-output tables to estimate total implied changes in output; finally, estimates of college- and non-college-educated labor per unit of output from U.S. data were used to estimate the factor content of the lost output.

What the estimate shows is that rising trade deficits have made the United States a consistent importer of goods produced both by highly educated and by less educated labor- that is, the U.S. picture looks like figure 11, where factor content arises from a trade deficit as well as from comparative advantage, rather than figure 10, where the only effect is from comparative advantage. Nonetheless, before 1989 the estimated effect of trade was a relative increase in the effective supply of less educated labor. 
Table 4. College- and Non-College-Educated Workers Displaced by Trade Percent of all workers displaced

\begin{tabular}{lcc}
\hline Period & ${\text { College } \text { graduates }^{\mathrm{b}}}$ & Non-college graduates $^{-}$ \\
\hline 1979-89 & 12.2 & 87.8 \\
1989-2000 & 21.2 & 78.9 \\
2000-04 & 21.3 & 78.7 \\
Memorandum: Shares of & 25.6 & 74.4 \\
$\quad$ total employment, 2000 & &
\end{tabular}

Source: Mishel, Bernstein, and Allegretto (2006).

a. Percentages may not sum to 100 because of rounding.

b. Individuals attending four years of college or more.

Since then, however, the calculations of Mishel, Bernstein, and Allegretto indicate little net effect of trade on relative effective factor supplies. The obvious explanation lies in the trends illustrated in figures 4 and 5: although the traditional manufactured exports of developing countries to the United States are labor-intensive goods like apparel, the growth in developing country exports has been concentrated in nontraditional sectors, especially computers and electronics. As the next section will show, the apparently strong comparative advantage of developing countries in these industries seems anomalous-unless the exports of developing countries are concentrated in unskilled labor-intensive subsectors within these industries.

\section{Within-Industry Specialization and the Problem of Interpretation}

A useful overview of the seemingly anomalous nature of some developing country exports can be obtained by using a technique suggested by John Romalis. ${ }^{19}$ Romalis provided impressive evidence of the continuing relevance of Heckscher-Ohlin trade theory based on an analysis of the sources of U.S. manufactured imports. He showed that the United States does tend, systematically, to import skilled labor-intensive goods from developed countries and unskilled labor-intensive goods from developing countries, although the relationship is far from perfect. He ascribed the imperfection to the interaction of product differentiation and transport costs..$^{20} \mathrm{An}$

19. Romalis (2004).

20. As modeled in Krugman (1980). 
Figure 12. Developing Country Shares of U.S. Imports by Industry and Industry Skill Intensity, 2006

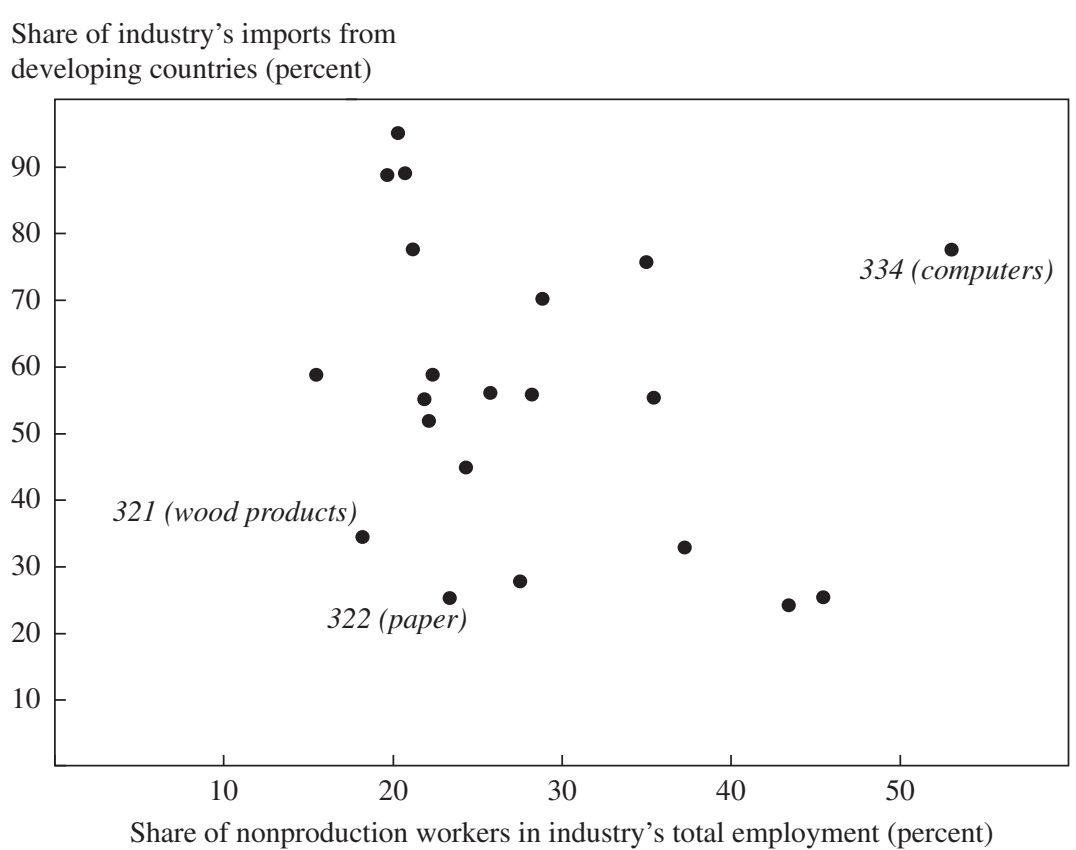

Sources: U.S. International Trade Commission DataWeb and U.S. Department of Commerce. a. Each observation represents a single industry at the NAICS three-digit level.

alternative interpretation, of course, is that the evidence is blurred by measurement error.

Figure 12 is a simple Romalis scatterplot, deliberately conducted at a relatively high level of aggregation. The data points are three-digit NAICS industries. The horizontal axis shows skill intensity as proxied by the share of nonproduction workers in employment. The vertical axis shows the share of developing countries in U.S. imports within the given industry. It is immediately apparent that most industries fall along a downward-sloping "main sequence," in which developing countries tend to export unskilled labor-intensive goods, with apparel and other traditional developing country exports at the upper left.

I have identified the industries that lie clearly off this main sequence. The industries at the lower left pose little puzzle: the paper and wood products industries are not very skill-intensive, but U.S. imports within these industries are, for reasons of resource abundance and geography, dominated by Canada. (They have lumberjacks, and that's OK.) But what is one 
to make of NAICS 334, computer and electronic products? In U.S. data it ranks as the most skill intensive of industries, yet it is also an industry in which more than three-quarters of imports come from developing countries, especially China.

It seems a foregone conclusion that aggregation is a serious problem here; why not use more disaggregated data? The answer is that within the limits of current data, there is little that can be done.

First of all, factor content analyses are limited by the level of disaggregation of the input-output table, which is at the four-digit level. A four-digit version of figure 12 would look essentially the same: all the components of NAICS 334 would remain in the upper right corner. And even finer levels of disaggregation are of relatively little help. To see why, consider the five six-digit sectors with the largest U.S. value added within computers and electronics, which collectively account for 57 percent of the total:

334413 Semiconductor and related device $\mathrm{mfg}$.

334111 Electronic computer $\mathrm{mfg}$.

334511 Search, detection, navigation, and guidance instrument $\mathrm{mfg}$.

334220 Radio and TV broadcasting and wireless communications equipment $\mathrm{mfg}$.

334210 Telephone apparatus $\mathrm{mfg}$.

These are not homogeneous sectors. They are, however, globalized industries, and it is easy to find qualitative information suggesting a division of labor between skill-intensive operations and less skill-intensive operations within each industry. Consider the following four examples.

\section{Computers}

There is a clear division between the types of computers produced in emerging Asia-primarily relatively low-end, standardized productsand those produced in developed countries. Probably even more important, computer production involves many stages, which are commonly split between developed and developing economies in a way clearly related to skill intensity. This paper was written on a Lenovo notebook computer. Lenovo, which took over the ThinkPad line from IBM, is famously a Chinese firm whose headquarters and product planning operations are in North Carolina, and many of whose components are produced in developed countries. These operations help make the computer industry look highly skill intensive, if one relies on data from the U.S. Census of Manufactures; this is not, however, a good representation of what the industry looks like in China. 
The standard caricature of the computer industry is that Japan and the United States make the innards, and then China adds the plastic shell. Although the reality is not quite that simple, Judith Dean, K. C. Fung, and Zhi Wang estimate that imported inputs accounted for 57 percent of the value of Chinese computer exports in 2002. ${ }^{21}$ Similarly, imported inputs accounted for 41 percent of Chinese exports of electronic devices by value, and for 46 percent for electronic appliances and 59 percent for communications equipment. And there is little question that in each case the imported inputs are much more skill intensive than the Chinese component of the process.

\section{The iPod}

Greg Linden, Kenneth Kraemer, and Jason Dedrick have made a widely publicized effort to figure out "who captures the value" from the Apple iPod, the enormously popular portable media player. ${ }^{22}$ The study illustrates just how difficult it is to assign value added on the basis of trade flows.

The iPod is assembled in China, so that iPod imports show up as imports from China. However, assembly and testing appear to account for less than 3 percent of an iPod's total input cost. The hard drive, which accounts for about half the iPod's price, is produced in China, but a considerable part of the hard drive's value presumably comes from components made elsewhere ${ }^{23}$ so that the Chinese component is probably quite unskilled labor intensive. The next most valuable component, the display, is made in Japan; crucial chips are made in the United States or Taiwan; and so on.

Apple iPod imports are presumably counted under NAICS 334310, audio and video equipment manufacturing. Yet it is clear from Linden, Kraemer, and Dedrick's study that trying to estimate the factor content of these imports using U.S. averages for that sector is wasted effort.

\section{Semiconductors}

Semiconductors might seem like a more homogeneous product than computers or iPods. But even the semiconductor industry is marked by an international division of labor that places skilled labor-intensive operations in developed countries and unskilled labor-intensive operations in developing countries. As in the case of computers, there is clear horizontal

21. Dean, Fung, and Wang (2007).

22. Linden, Kraemer, and Dedrick (2007).

23. By the mid-1990s, the assembly of hard disk drives had already moved overwhelmingly to low-wage countries. Yet the United States and Japan still accounted for 65 percent of the wages paid by the industry considered as a whole. See Gourevitch, Bohn, and McKendrick (2000). 
specialization, with developing countries producing standardized commodity products: the manufacture of "standard" chips, which are used in many devices, is dominated by emerging Asia, but much higher-end production remains in developed countries.

There is also extensive vertical specialization. For example, Intel's manufacturing facilities are of two kinds, because production takes place in two stages. First, circuits are printed, using photolithography, on large disks of silicon at wafer fabrication plants, or "fabs." Then the wafers are sent to assembly and testing facilities, where, according to an Intel fact sheet, "each wafer is cut into individual silicon dies, placed within external packages, and tested for functionality." 24

Where are these operations located? Intel has wafer fabs in the United States, Ireland, and Israel. All of its assembly and testing sites, by contrast, are in developing countries: China, Costa Rica, Malaysia, and the Philippines, with a new site under construction in Vietnam. In other words, within microprocessor manufacture, which is just one piece of the six-digit semiconductor sector, one stage of production is largely confined to developed economies, whereas another is largely confined to very low wage countries.

\section{Auto Parts}

Figure 5 showed the predominant role of computers and electronics in the growth of U.S. imports from developing countries. There has also, however, been significant growth in imports of automotive products, mainly from Mexico. A look at automotive trade shows the same pattern of vertical specialization and disintegration as in computers and electronics, with Mexico taking over labor-intensive niches within the industry.

Thomas Klier and James Rubenstein, in a survey of the growing trade in auto parts, describe some key aspects of that trade:

At the least-skilled end was electrical wiring; $80 \%$ of wiring imports originate in Mexico, which emerged as the leading producer of wiring harnesses in the 1970s. Relatively labor-intensive and easy to ship, wiring was the first major component to be imported in large numbers. Imports in chassis, at $\$ 15$ billion the largest of the remaining systems, have made the greatest percentage gains since 1990. The chassis has become the principal "battleground" system between domestic and imported sources. Engineering advances have transformed chassis modules from high-cost production items requiring skilled labor to low-cost "generic" items highly sensitive to labor cost savings. ${ }^{25}$

24. See "Frequently Asked Questions about Intel Manufacturing and ProductionRelated Services," www.intel.com/pressroom/kits/manufacturing/manufacturing_qa.htm.

25. Klier and Rubenstein (2006, p. 2). 
All these examples suggest a data problem: numbers showing a rapid rise in developing country exports, and Chinese exports in particular, within sectors that are skill intensive in the United States need to be taken with large doses of salt. As Jianmin Jin puts it, "The kind of gap seen in the electronic information industry between the rapid expansion of the scale of the industry coupled with a low value-added structure is evidence for China's role as an assembly base that is dependent upon overseas parts, intermediary goods, and capital goods." 26

Peter Schott offers additional evidence based on unit values (import prices divided by import quantity), which are available in sectors where the goods that the United States imports can be easily measured in physical units (for example, dozens of shirts, square meters of carpet, or pounds of chemicals). ${ }^{27}$ It turns out that Chinese goods imported by the United States have substantially lower unit values than goods within the same industries imported from developed countries; for example, the shirts that the United States imports from China are cheaper than shirts imported from Italy. Furthermore, the gap in unit values has been rising over time, suggesting that the relative sophistication of Chinese exports within any given industry has been declining.

\section{Vertical Specialization and Wage Inequality}

The broad picture, then, is that the apparent sophistication of imports from developing countries is in large part a statistical illusion. Developing countries in general, and China in particular, are probably specializing in very different niches within industries than the United States. But how does all of this bear on the question of whether rising trade with developing countries has led to rising wage inequality in the United States?

Several recent analyses have argued that such specialization in effect protects developed country workers from the distributional effects of trade by placing such countries in a different "cone of diversification" from developing countries. ${ }^{28}$ Figure 13 illustrates the concept of cones of specialization, using a Lerner diagram. The curves represent unit-value isoquants—combinations of skilled and unskilled labor inputs that produce an equal value (say, \$100) of good X, Y, or Z at current market prices. The downward-sloping lines $\mathrm{NN}$ and SS represent relative factor prices in

26. Jin (2006).

27. Schott (2006).

28. See, in particular, Schott (2001) and Lawrence (2008). 
Figure 13. Cones of Specialization

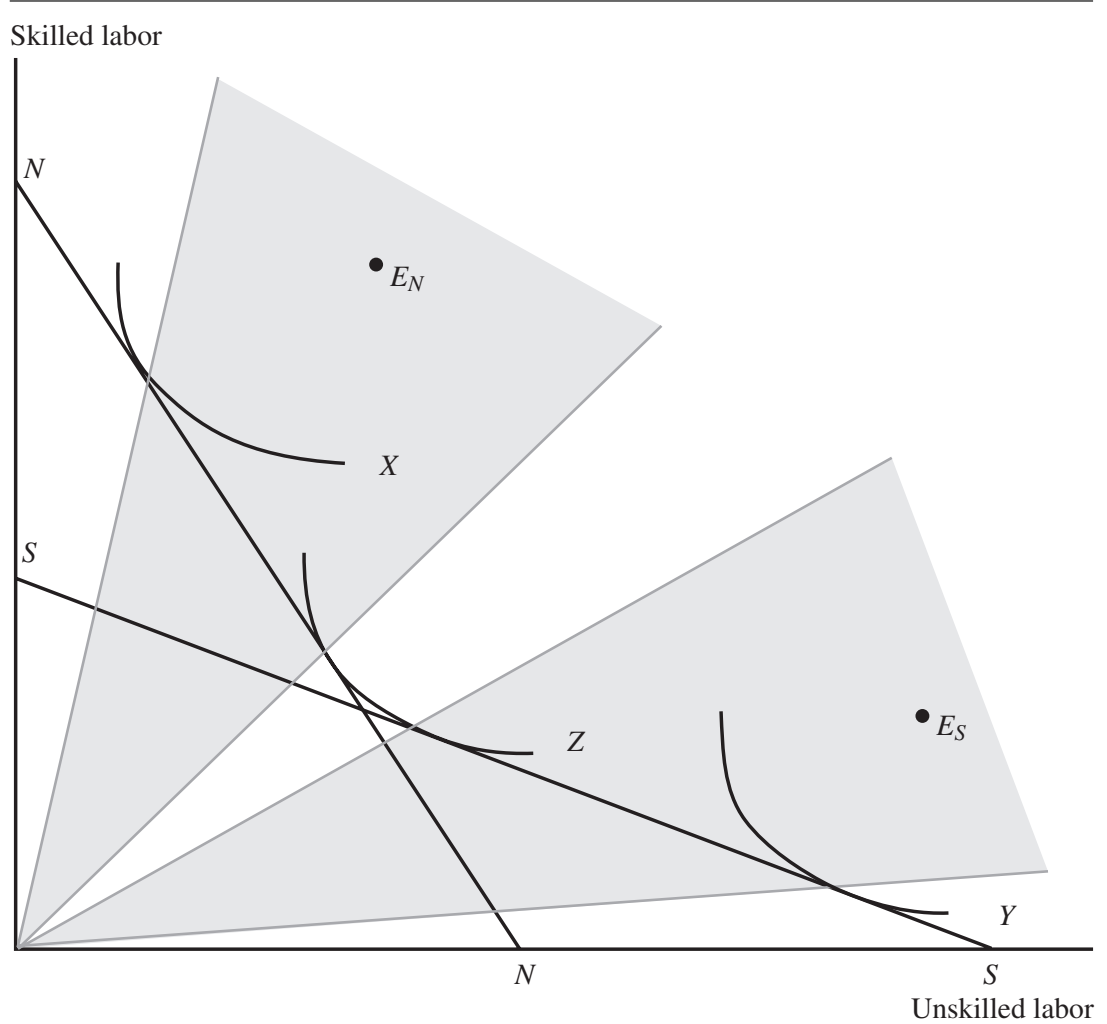

Source: Author's model described in the text.

developed countries and developing countries, respectively, and points $E_{N}$ and $\mathrm{E}_{\mathrm{S}}$ their aggregate factor endowments.

As drawn, the figure is consistent with a pattern of specialization in which both developed and developing countries produce good Z, developed countries also produce the skilled labor-intensive good $X$, and developing countries also produce the unskilled labor-intensive good Y. Because both types of countries produce $\mathrm{Z}$, the two factor-price lines represent equal value; in developed countries the cost of producing $X$ is the same as that of producing an equal value of $\mathrm{Z}$, so both goods can be produced there; the same is true of $\mathrm{Z}$ and $\mathrm{Y}$ in developing countries; but producing a unit of $\mathrm{X}$ is more expensive in developing countries than in developed countries, whereas producing a unit of $\mathrm{Z}$ is less expensive. Each country is able to 
fully employ all its workers because its endowment lies in the cone of diversification illustrated in figure 13 .

The famous proposition that trade leads to equalization of factor prices-a proposition closely linked to the Stolper-Samuelson effectapplies only to countries that lie in the same cone. So the suggestion that developing and developed countries lie in different cones may seem to obviate concerns about the distributional effects of trade. Thus, Schott asserts that

If all countries produce all goods, unskilled workers in the U.S. can be adversely affected by a drop in the world price of labor-intensive imports.... Specialization, however, means that U.S. firms produce a capital-intensive mix of goods and are therefore not threatened by cheap imports. ${ }^{29}$

Lawrence makes a similar argument. ${ }^{30}$ And in fact my 1995 paper suggested that the prospect of specialization offered one reason to doubt whether the distributional effects of trade could get much larger than they were in the early 1990s. ${ }^{31}$

But the evidence on specialization within industries, and on vertical specialization in particular, calls this interpretation into doubt. The shock behind rapid growth in developing country exports of manufactured goods does not appear to be developing country growth leading to falling prices of traditional exports such as apparel. Instead what seems to be happening is a breakup of the value chain that allows developing countries to take over unskilled labor-intensive portions of skilled labor-intensive industries. And this process can have consequences that closely resemble the Stolper-Samuelson effect.

This point is difficult to make analytically but comes across clearly in a numerical example. Assume that there are two final goods, $\mathrm{Y}$ and $\mathrm{Z}$, produced using two factors of production, skilled labor $\mathrm{S}$ and unskilled labor L. There are also two countries, a skilled labor-abundant North and an unskilled labor-abundant South. Production of $\mathrm{Z}$ is unskilled labor intensive. Production of Y takes place in two stages: a skilled labor-intensive "component" stage $\mathrm{X}$ and an unskilled labor-intensive "assembly" stage.

Production functions and utility for the final goods are assumed to be Cobb-Douglas. The assumed parameters and resource endowments are as follows:

29. Schott (2000).

30. Lawrence (2008).

31. Krugman (1995). 


$\begin{array}{ll}\text { Skilled labor share in X } & 0.8 \\ \text { Unskilled labor share in X } & 0.2 \\ \text { X share in Y } & 0.9 \\ \text { Skilled labor share in Y } & 0.01 \\ \text { Unskilled labor share in Y } & 0.09 \\ \text { Skilled labor share in Z } & 0.27 \\ \text { Unskilled labor share in Z } & 0.73 \\ \text { Share of Y in spending } & 0.5 \\ \text { Share of Z in spending } & 0.5 \\ \text { Skilled labor force in North } & 1.0 \\ \text { Unskilled labor force in North } & 1.0 \\ \text { Skilled labor force in South } & 0.1 \\ \text { Unskilled labor force in South } & 0.5\end{array}$

The model is initially solved for equilibrium in the developed North in the absence of trade. I then consider two trade scenarios. Case I assumes that $\mathrm{X}$ and $\mathrm{Y}$ must be physically co-located, so that there is in effect an aggregate $\mathrm{XY}$ industry. Case II allows $\mathrm{X}$ and $\mathrm{Y}$ to be separated, with unskilled labor-intensive assembly taking place in a different country from the skilled labor-intensive component production.

Solution of the model requires determining both the pattern of specialization and relative goods prices. In practice I began by guessing at the specialization pattern. I then used an initial guess at factor prices to yield implied goods outputs, used those outputs to derive goods prices, used those prices to derive a new estimate of factor prices, and iterated until convergence. The final step was to confirm that the implied factor prices did in fact support the assumed pattern of specialization. Given goods prices and factor prices, it was possible to calculate real wages of skilled and unskilled labor in each country. In the case in which $\mathrm{X}$ and $\mathrm{Y}$ had to be co-located, the pattern of specialization and the associated factor prices were as illustrated in figure 14. The developing South specialized in the production of unskilled labor-intensive $Z$, whereas the North remained unspecialized, producing both the skilled labor-intensive composite $X Y$ and $\mathrm{Z}$. The relative price of $\mathrm{Z}$ was lower in the developed economy than it would have been in the absence of trade - the standard Stolper-Samuelson effect. As the first column in table 5 shows, trade raises the real wages of skilled workers while reducing those of unskilled workers.

But what happens if X and Y can be separated? Then the pattern of specialization becomes that illustrated in figure 13 . Both countries continue to produce $\mathrm{Z}$; meanwhile the unskilled labor-intensive portion of $\mathrm{XY}$ moves 
Figure 14. Vertical Specialization with Industry Co-Location

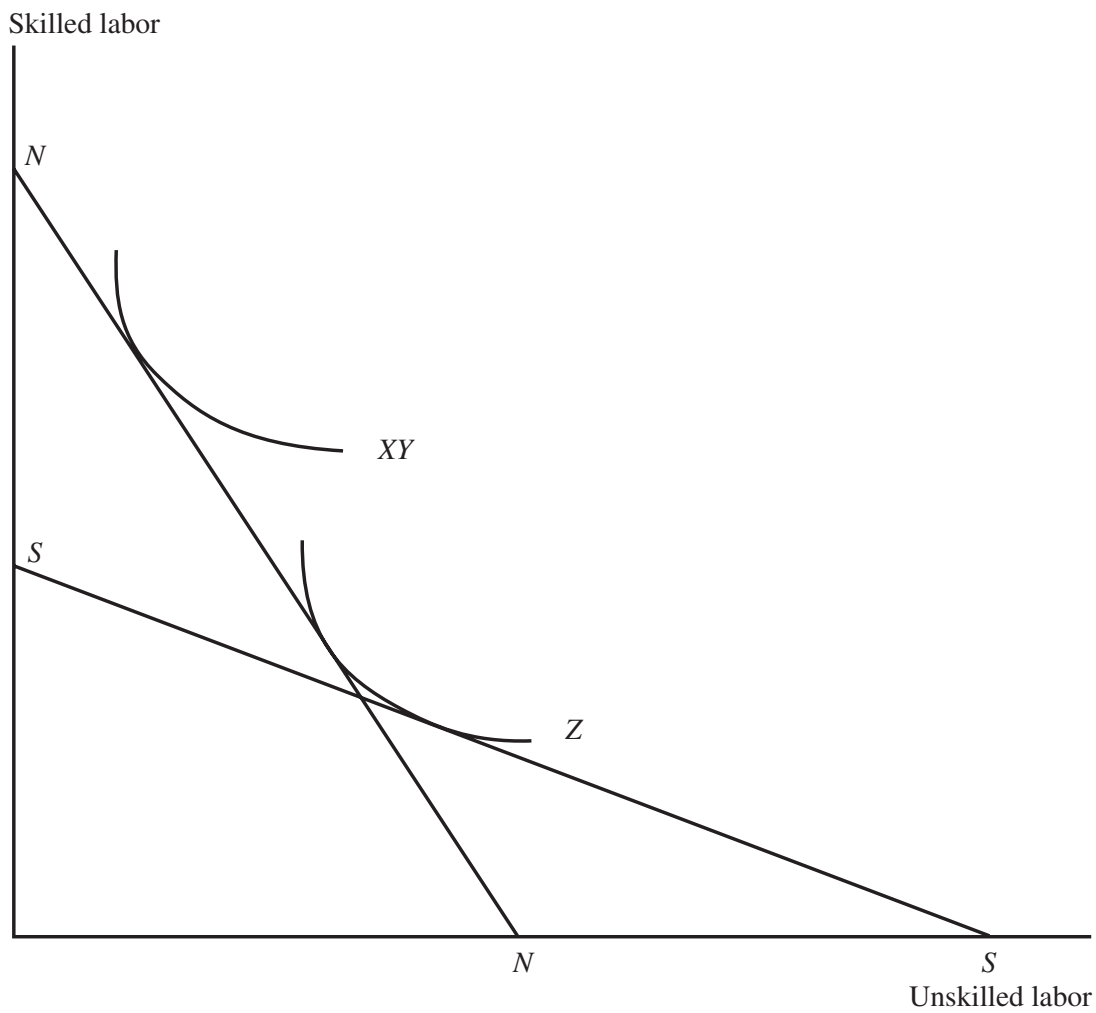

Source: Author's model described in the text.

Table 5. Changes in Real Wages under Industry Co-Location and Vertical Specialization ${ }^{\mathrm{a}}$

Percent

Industries co-located

Vertical specialization

Skilled workers

$+13.4$

$+15.9$

Unskilled workers

$-11.8$

$-13.6$

Memorandum: Import share

13.6

53.5 in North GDP

Source: Author's calculations using the model described in the text.

a. Calculated as described in the text. 
Figure 15. North-South Trade before and after Vertical Specialization

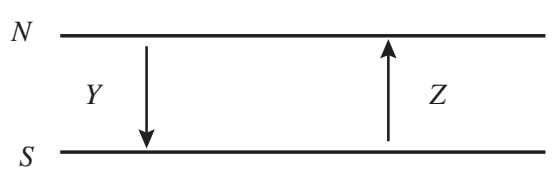

Before vertical specialization

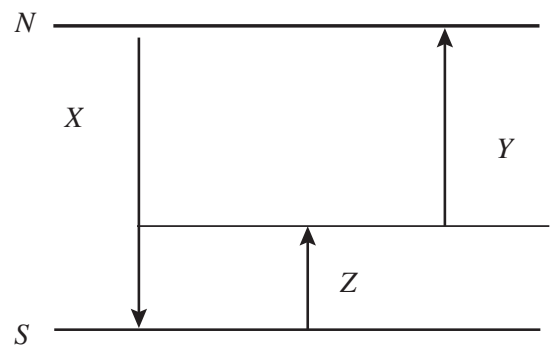

After vertical specialization

Source: Author's model described in the text.

to the developing country while the skilled labor-intensive portion remains in the developed country.

Figure 15 schematically illustrates the pattern of trade associated with each case, with the length of the arrows indicating the value of exports from each country to the other. When X and Y must be co-located, North exports $\mathrm{Y}$ to South and imports Z. (Think of this as trading computers for apparel.) When it becomes possible to engage in vertical specialization, North exports $X$ (for example, computer components) to South, and imports both $\mathrm{Z}$ (apparel) and $\mathrm{Y}$ (assembled computers). I have drawn the figure to suggest a large increase in the volume of trade. In the numerical example, the share of imports in North's GDP rises from 13.6 percent to 53.5 percent.

In a qualitative sense the change illustrated in figure 15 seems to resemble the actual change in North-South trade since the early 1990s, as documented in this paper. The share of developed country GDP spent on imports from developing countries rises sharply, because components are shipped to developing countries for assembly, and the assembled goods are then exported back to the developed world. If $\mathrm{X}$ and $\mathrm{Y}$ continue to be classified as part of the same industry, however, factor content calculations based on developed country unit input coefficients will not suggest an increase in effective imports of unskilled labor. And the measured export 
mix of developing countries will seem to move upscale, toward more sophisticated products.

Yet as the second column in table 5 shows, the actual effects on workers in the developed economy reflect a sort of Stolper-Samuelson effect: the real wages of skilled workers rise, while those of unskilled workers fall. Intuitively, the new ability to outsource unskilled labor-intensive industry segments to the developing world depresses the demand for less skilled workers, a shock not captured by data that lump unskilled labor-intensive "assembly" operations together with skilled labor-intensive "component" manufacture.

However, this example does suggest that the type of calculation performed by Bivens, ${ }^{32}$ in which the distributional effects of trade are assumed to be essentially proportional to the import share- a calculation suggested, admittedly, by my own 1995 paper-may exaggerate the distributional effects of recent trade growth. In this example the trade share grows fourfold, but the distributional effects do not grow in proportion. The reason, intuitively, is that much of the content of the new imports from developing countries is actually skilled labor-intensive production from developed countries, so that not as much unskilled labor is displaced as the raw import figures seem to suggest. If the United States imports computers from China, and China assembles computers largely from components made in Japan, only the assembly share of the sales price reflects unskilled labor-intensive imports; the rest is indirect importing from a country whose factor prices are similar to U.S. factor prices. Nonetheless, the analysis presented here indicates that the rapid rise in manufactures imports from developing countries probably is, indeed, a force for growing inequality, and that factor content calculations suggesting otherwise are missing the essence of what is happening.

\section{Implications of the Analysis}

The starting point of this paper was the observation that the consensus that trade has only modest effects on inequality rests on relatively old datathat there has been a dramatic increase in manufactured imports from developing countries since the early 1990s. And it is probably true that this increase has been a force for greater inequality in the United States and other developed countries.

What really comes through from the analysis here, however, is the extent to which the changing nature of world trade has outpaced economists' ability to engage in secure quantitative analysis-even though this

32. Bivens (2007). 
paper sets to one side the growth in services outsourcing, which has created so much anxiety in recent years. Plain old trade in physical goods has become remarkably exotic.

In particular, the surge in developing country exports of manufactures involves a peculiar concentration on apparently sophisticated products, which seems at first to put worries about distributional effects to rest. Yet there is good reason to believe that the apparent sophistication of developing country exports is largely a statistical illusion, created by the phenomenon of vertical specialization in a world of low trade costs.

How can the actual effect of rising trade on wages be quantified? The answer, given the current state of the data, is that it can't. As I have said, it is likely that the rapid growth of trade since the early 1990s has had significant distributional effects. Putting numbers on these effects, however, will require a much better understanding of the increasingly fine-grained nature of international specialization and trade. 


\section{References}

Bernanke, Ben. 2007. "Speech before the Greater Omaha Chamber of Commerce." Washington: Federal Reserve.

Bivens, Josh. 2007. "Globalization, American Wages, and Inequality: Past, Present, and Future.” EPI Working Paper 279. Washington: Economic Policy Institute.

Blinder, Alan. 2006. "Offshoring: The Next Industrial Revolution." Foreign Affairs 85, no. 2: 113-28.

Borjas, George, Richard B. Freeman, and Lawrence F. Katz. 1997. "How Much Do Immigration and Trade Affect Labor Market Outcomes?” BPEA, no. 1: $1-90$.

Bureau of Labor Statistics. 2006. "International Comparisons of Hourly Compensation Costs for Production Workers in Manufacturing." Washington.

Cline, William. 1997. Trade and Income Distribution. Washington: Institute for International Economics.

Dean, Judith, K. C. Fung, and Zhi Wang. 2007. "Measuring the Vertical Specialization in Chinese Trade." USITC Working Paper. Washington: U.S. International Trade Commission.

Faberman, R. Jason. 2004. "Gross Job Flows over the Last Two Business Cycles: Not All Recoveries Are Created Equal.” BLS Working Paper 372. Washington: Bureau of Labor Statistics.

Goldin, Claudia, and Lawrence F. Katz. 2007. "Long-Run Changes in the Wage Structure." BPEA, no. 2: 135-67.

Gourevitch, Peter, Roger Bohn, and David McKendrick. 2000. "Globalization of Production: Insights from the Hard Disk Drive Industry." World Development 28, no. 2: 301-17.

Hummels, David, Jun Ishii, and Kei-Mu Yi. 2001. "The Nature and Growth of Vertical Specialization in World Trade." Journal of International Economics 54: 75-96.

Jin, Jianmin. 2006. “The Current Status of China's Electronic Information Industry." Tokyo: Fujitsu Research Institute.

Klier, Thomas, and James Rubenstein. 2006. "Competition and Trade in the U.S. Auto Parts Sector.” Fed Letter 222. Federal Reserve Bank of Chicago.

Krugman, Paul R. 1980. "Scale Economies, Product Differentiation, and the Pattern of Trade." American Economic Review 70, no. 5: 950-59.

- 1995. "Growing World Trade: Causes and Consequences." BPEA, no. 1 (Spring): 327-77.

—. 1996. "But For, As If, and So What?" Massachusetts Institute of Technology.

- 2000. "Technology, Trade, and Factor Prices." Journal of International Economics 50, no. 1: 51-71.

Lawrence, Robert Z. 1996. Single World, Divided Nations? International Trade and OECD Labor Markets. Brookings. 
2008. Blue-Collar Blues: Is Trade to Blame for Rising US Income Inequality? Washington: Peterson Institute for International Economics.

Leamer, Edward. 1994. "Trade, Wages, and Revolving Door Ideas." Working Paper 4716. Cambridge, Mass.: National Bureau of Economic Research.

Linden, Greg, Kenneth Kraemer, and Jason Dedrick. 2007. "Who Captures Value in a Global Innovation System? The Case of Apple's iPod." University of California, Irvine.

Mishel, Lawrence, Jared Bernstein, and Sylvia Allegretto. 2006. The State of Working America 2006/2007. Cornell University Press and Economic Policy Institute.

Romalis, John. 2004. "Factor Proportions and the Structure of Commodity Trade." American Economic Review 94, no. 1: 67-97.

Schott, Peter. 2000. "One Size Fits All? Heckscher-Ohlin Specialization in International Production." Yale University.

_. 2001. "One Size Fits All? Heckscher-Ohlin Specialization in International Production." Working Paper 8244. Cambridge, Mass.: National Bureau of Economic Research.

2006. "The Relative Sophistication of Chinese Exports." Working Paper 12173. Cambridge, Mass.: National Bureau of Economic Research.

Stolper, Wolfgang, and Paul Samuelson. 1941. "Protection and Real Wages." Review of Economic Studies 9, no. 1: 58-73. 


\section{Comments and Discussion}

\section{COMMENT BY}

DOUGLAS A. IRWIN This paper is a much-needed follow-up to Paul Krugman's 1995 Brookings Paper on the growth of international trade. ${ }^{1} \mathrm{~A}$ key issue discussed in that paper, and a topic of much academic research at the time, was the role of increased trade in driving wage inequality in the United States. The general consensus from that work was that trade had played a relatively small role in depressing the relative wages of less skilled workers.

However, one of the most striking changes over the past thirteen years has been the large increase in U.S. imports from low-wage developing countries. As Krugman notes, the trade-and-wages research from the early and mid-1990s has not been updated to take into account developments such as NAFTA and the emergence of China as a major exporter. These changes might lead one to assume that the impact of trade on wages would be significantly greater than it was in studies that used data primarily from the 1980s. But since the answer is really not known, the topic is ripe for reconsideration.

Unfortunately, those expecting a definitive answer from Krugman's paper will be disappointed. As he concludes, "How can the actual effect of rising trade on wages be quantified? The answer, given the current state of the data, is that it can't." Alas, I must agree with Krugman that the question is going to be very difficult to answer. However, the available evidence suggests to me that trade is not playing a larger role in driving U.S. wage inequality today than it was a decade or two ago.

1. Paul R. Krugman, "Growing World Trade: Causes and Consequences," BPEA, no. 1 (Spring 1995): 327-77. 
Determining the impact of trade on the wage structure requires data on wages, data on trade, and a theory linking the two. Each of these critical components has a problem, which makes finding the trade-wage relationship very difficult. The first problem is that there are different, and sometimes conflicting, measures of wage inequality. Krugman focuses on the college-high school wage premium, which is frequently studied and has continued to grow over the past decade since the original trade-and-wages literature began to peter out. ${ }^{2}$ The rising returns to education may be plausibly related to increased trade, although Claudia Goldin and Lawrence Katz explain it more on the basis of a domestic story about the supply and demand for skilled workers. ${ }^{3}$

Yet there are many ways of parsing the wage data. In the 1990s economists frequently focused on how trade might have contributed to the increasing wage gap between nonproduction and production workers, presumably another proxy for white- and blue-collar workers. For example, Robert Feenstra and Gordon Hanson studied this wage gap closely and concluded that the outsourcing of production and assembly operations to developing countries could explain part of the rise. ${ }^{4}$

But as figure 1 shows, this wage gap has been narrowing since about 2000 , after most of this research was completed. Because production outsourcing has most likely continued since 2000, if not accelerated, I would venture the guess that the Feenstra-Hanson empirical model would not perform well out of sample; that is, it would probably predict a further increase in the nonproduction-production wage gap, because outsourcing has continued since 2000, whereas the wage gap has narrowed.

The simple point is that there are conflicting wage data, and not all suggest increasing inequality. ${ }^{5}$ Until there is clear-cut agreement on which wage series should command the most attention, no single cut at the data will be decisive.

2. See David H. Autor, Lawrence F. Katz, and Melissa S. Kearney, "Trends in U.S. Wage Inequality: Revising the Revisionists," Review of Economics and Statistics 90 (2008): $300-23$.

3. Claudia Goldin and Lawrence F. Katz, The Race between Education and Technology (Harvard University Press, 2008).

4. Robert C. Feenstra and Gordon H. Hanson, "The Impact of Outsourcing and HighTechnology Capital on Wages: Estimates for the U.S., 1979-1990," Quarterly Journal of Economics 114, no. 3 (1999): 907-40.

5. For example, much of the recent rise in income inequality has been driven by the top 1 percent of the distribution, which is presumably related to financial markets and not international trade. 
Figure 1. Ratio of Nonproduction to Production Wages in Manufacturing, 1963-2005a

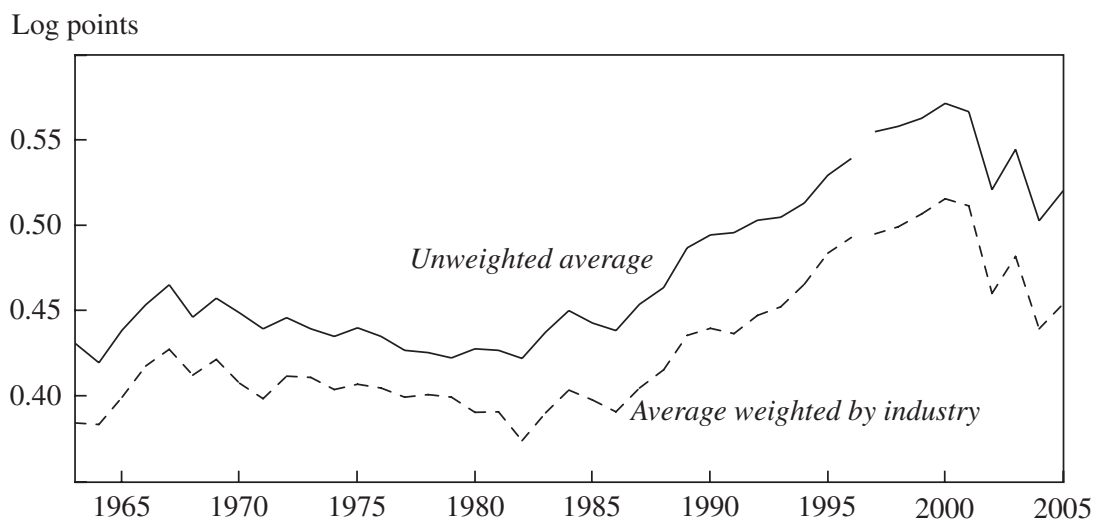

Source: Nino Sitchinava, “Trade, Technology, and Wage Inequality: Evidence from U.S. Manufacturing, 1989-2004," working paper, Department of Economics, University of Oregon (2007).

a. Data from before 1997 use Standard Industrial Classification codes; data for 1997 and after use North American Industry Classification System codes.

The second problem with determining the trade-wages relationship is that the trade data, as Krugman notes, have become really problematic. The impact of trade on wages depends upon the factor content of imports. But the trade data simply record the country from which an imported product arrives, not necessarily where it was produced or where its components came from. Since trade in intermediate goods is flourishing, one cannot simply infer the factor content of a product from its country of origin.

Krugman mentions the classic case of the Apple iPod: recorded as a $\$ 150$ import from China, the iPod embodies just a few dollars of Chinese labor in assembly and a few more dollars of Chinese labor related to production of the hard drive. To treat this $\$ 150$ import from China as an import of $\$ 150$ of unskilled labor would grossly exaggerate the low-wage factor content of the product. Dean, Fung, and Wang conclude that 36 percent of the value of Chinese exports in the aggregate consists of imported intermediate components, a figure that is much higher in some sectors such as electronics. ${ }^{6}$ This makes it misleading to use the value of imports to infer something about the factor content of trade. As a result, as Krugman notes, the impact of imports on the income distribution is not going to be proportional to the import share.

6. Judy Dean, K. C. Fung, and Zhi Wang, "Measuring the Vertical Specialization in Chinese Trade," USITC Working Paper (Washington: U.S. International Trade Commission, 2007). 
The final problem in determining the impact of trade on wages is that one needs a theoretical framework for thinking about the two. When trade economists think about the issue, the Stolper-Samuelson theorem immediately comes to mind. Stolper-Samuelson is a magnificent result, but economists should be somewhat cautious in applying it to the world today. The flip side of the Stolper-Samuelson result is that the relative wage of unskilled workers in developing countries should be increasing, yet the opposite is the case. ${ }^{7}$ This suggests that there is something else going on in the world, or that the strong Stolper-Samuelson result (based on a simple model with two final goods and two factors of production) does not capture what a richer version with internationally mobile capital and trade in intermediate goods might. Our models are very simple, and the world is a bit more complicated.

Given the variety of wage data, the problems with the trade data, and the questions about the theory, does this mean that economists can say nothing about the issue? Fortunately not. One simple exercise might put an upper bound on the impact of trade on wages. As noted, one cannot assume that the impact of imports from low-wage countries on U.S. wages is proportional to the import share, because those imports use a lot of components made in high-wage countries. The implication is that using the import share will result in an exaggerated view of the impact on wages.

Bivens does this exercise and brings Krugman's 1995 findings up to date, ${ }^{8}$ but the result is surprising: although trade increased substantially between 1992 and 2005, so did the college-high school wage gap, and hence the share of that inequality that can be attributed to trade did not change. By the rough calculation in table 1, trade was responsible for about 10 percent of wage inequality in the 1979-92 period, and about 10 percent of wage inequality in the 1979-2005 period..$^{9}$ And for the reasons already mentioned, the latter is an overstatement of the impact of trade on wages, so if the impact was relatively small in the earlier period, it may be even smaller more recently.

Furthermore, there has been some recent research on the growth of wage inequality in manufacturing since the earlier literature. Nino

7. Pinelopi Goldberg and Nina Pavcnik, "Distributional Effects of Globalization in Developing Countries," Journal of Economic Literature 45, no. 1 (2007): 39-82.

8. Josh Bivens, "Globalization, American Wages, and Inequality: Past, Present, and Future," EPI Working Paper 279 (Washington: Economic Policy Institute, 2007).

9. This is a very simplistic comparison, but in his comment Lawrence Katz similarly concludes that the Bivens calculation implies that trade is responsible for about 15 percent of the increase in inequality since 1979 . 
Table 1. Impact of Trade on Wage Inequality Percent

\begin{tabular}{lcc}
\hline & Krugman (1995) & Bivens (2007) \\
\hline Period covered & $1979-92$ & $1979-2005$ \\
Estimated effect of trade on & +4.7 & +6.9 \\
$\quad$ skilled-unskilled wage ratio & & +65.0 \\
$\begin{array}{l}\text { Change in college-high school wage ratio } \\
\text { Proportion of change in wage ratio }\end{array} \quad$ & 11.5 & 11 \\
$\quad$ due to estimated trade effect & & \\
\hline
\end{tabular}

Sources: Paul R. Krugman, "Growing World Trade: Causes and Consequences," BPEA, no. 2 (Spring 1995): 327-77; Josh Bivens, "Globalization, American Wages, and Inequality," EPI Working Paper (Washington: Economic Policy Institute, September 6, 2007); author's calculations.

a. From David H. Autor, Lawrence F. Katz, and Melissa S. Kearney, "Trends in U.S. Wage Inequality: Revising the Revisionists," Review of Economics and Statistics 90 (May 2008): 300-23.

Sitchinava concludes that "the relative contribution of trade is sensitive to the data and the type of variables used in the estimation." measures of outsourcing, Sitchinava finds that two sources of trade tend to work in different directions with respect to wages: whereas trade in intermediate inputs and final goods tends to increase wage inequality, trade in service inputs tends to decrease it. This mutes the effect of trade on overall wage inequality. As a result, given the increase in services trade, it could be that trade is less of a factor in driving wage inequality now than it was in the 1980s.

To conclude on a provocative note: does it matter how much inequality is being driven by trade? It would certainly matter for our perception of the world and the demands that might be made to limit trade. But how much would the policy recommendations of, say, the median Massachusetts Avenue economist (Brookings Institution, Peterson Institute for International Economics, Center for Global Development, Council on Foreign Relations, Johns Hopkins School for Advanced International Studies, etc.) change depending upon that figure? I suspect the policy advice would be the same regardless of whether trade was found to have been responsible for 4 percent or 40 percent of a given amount of wage inequality. That response would probably be as follows: inequality may be undesirable, but it should be addressed not by closing markets through greater protection-

10. Nino Sitchinava, "Trade, Technology, and Wage Inequality: Evidence from U.S. Manufacturing, 1989-2004," working paper, Department of Economics, University of Oregon (2007). As she notes, "My preliminary estimation indicates that the standard measure of foreign outsourcing of intermediate goods, proposed by [Feenstra and Hanson] . . . and commonly used in the literature, suffers from severe measurement errors that prohibit the estimation of the impact of trade in intermediate inputs on the wage dispersion of the 1990s." 
ism, but by more progressive income taxation, a stronger social safety net, and more assistance for displaced workers. Of course, this is just speculation on my part.

\section{COMMENT BY}

LAWRENCE F. KATZ U.S. wage inequality and educational wage differentials have expanded dramatically since 1980. Trade with developing countries has increased rapidly over the same period. Many commentators, politicians, potential voters, labor leaders, and business leaders believe there is a strong connection between globalization (particularly increased imports from and outsourcing to lower-wage countries), on the one hand, and rising economic inequality and stagnating living standards for noncollege-educated and other "middle-class" U.S. workers and their families. But as Paul Krugman summarizes in table 1 of his engaging paper, most serious quantitative research using data through the early to mid-1990s found only small to modest impacts of North-South trade on U.S. wage inequality and skill differentials.

I am delighted to see Krugman, a major voice for both analytical rigor and common sense in the trade-and-wages debates of the 1990s, return to these issues; in particular, I am delighted that his paper takes into account the large growth in U.S. trade with developing countries since the mid1990s and the substantial changes in the nature of North-South trade. In this comment I will first summarize Krugman's analysis and my interpretation of his framework and findings. I will then comment on how far his approach based on the growing vertical fragmentation of international supply chains takes us toward understanding some of the existing challenges for trade-based explanations of growing U.S. wage inequality. Finally, I will speculate on directions for further research to better understand how globalization is affecting the U.S. labor market.

WHAT KRUGMAN HAS ACCOMPLISHED. Krugman documents that U.S. imports of manufactured goods from developing countries expanded from under 3 percent of GDP in the early 1990s to around 6 percent in 2006. He also shows that the developing countries accounting for the bulk of this expansion (especially China and Mexico) have much lower wages relative to developed countries than did the main sources of U.S. "low-wage" imports in the early 1990s. For Krugman these two factors suggest that growing North-South trade in manufactures should have substantially larger impacts on U.S. wage inequality today than past studies found using data covering the U.S. experience of the 1980s and early 1990s. 
Nevertheless, updated micro factor content analyses of the disaggregated industry composition of U.S. trade in manufactures with developing countries using data through the mid-2000s continue to imply only small trade impacts on the U.S. wage structure. ${ }^{1}$ Krugman shows that the reason is the growing apparent sophistication of U.S. imports from developing countries. The United States increasingly imports goods from developing countries in skill-intensive sectors such as computers and electronic products. Even when one disaggregates trade flows to the four-digit NAICS level, the skill content of U.S. imports from developing countries looks very similar to the overall skill endowment of the U.S. workforce, implying little impact of such trade flows on wage inequality.

The core of Krugman's paper is an attempt to address the apparent paradox of rising U.S. trade with low-wage countries showing up in increased U.S. imports of goods in skill-intensive sectors. Krugman's resolution of this paradox is that the data used in standard factor content calculations suffer from a severe aggregation bias, driven by the vertical fragmentation of production through globalized supply chains in which the unskilled labor-intensive niches (such as assembly stages) of skilled labor-intensive sectors are shifted to developing countries. Thus, the apparent sophistication of imports from developing countries is partly an aggregation illusion, with the value added from developing countries being in the unskilled labor-intensive niches (or stages of production) in each (four-digit NAICS) industry. He presents some well-known but insightful examples that illustrate such vertical fragmentation of production by skill content across countries for computers (Lenovo notebooks), auto parts, semiconductors, and the iPod. In fact, detailed recent work by Robert Koopman, Zhi Wang, and Shang-Jin Wei suggests that the foreign content in China's exports is about 50 percent overall and around 80 percent in sophisticated sectors such as electronic devices. ${ }^{2}$ Krugman suggests that such vertical fragmentation of production means that growing trade with developing countries may have a larger impact on wage inequality in developed countries than traditional micro factor content studies indicate.

1. Such studies include Robert Z. Lawrence, Blue-Collar Blues: Is Trade to Blame for Rising US Income Inequality? (Washington: Peterson Institute for International Economics, 2008), and Lawrence Mishel, Jared Bernstein, and Sylvia Allegretto, The State of Working America: 2006/2007 (Cornell University Press and Economics Policy Institute, 2006).

2. Robert Koopman, Zhi Wang, and Shang-Jin Wei, "How Much of Chinese Exports Is Really Made in China? Assessing Domestic Value-Added When Processing Trade Is Pervasive," Working Paper 14109 (Cambridge, Mass.: National Bureau of Economic Research, June 2008). 
Krugman illustrates this possibility through an extension of a simple Heckscher-Ohlin factor endowment-driven North-South trade model to incorporate a skilled labor-intensive sector (XY) with two stages of production (a skilled labor-intensive part $X$ and an unskilled labor-intensive part Y) and an unskilled labor-intensive sector (Z). My interpretation of this framework is that in the early stages of the recent period of globalization (the 1980s to the early 1990s), increased international integration led to traditional trade flows of skilled labor-intensive goods (XY) being exported from the North in return for unskilled labor-intensive traditional imports (Z), such as apparel and shoes, from the South. The second stage of globalization (from the early 1990s to the present) has involved the vertical fragmentation of skilled labor-intensive sectors (such as computers), so that XY fragments, with X being done in the North and Y increasingly being done in the South. This leads to increased exports from the South to the North that get classified as sophisticated goods in the XY sector. The new ability of the North to outsource unskilled labor-intensive industry segments to the South can have a Stolper-Samuelson-type effect, benefiting skilled workers and harming unskilled workers in the North, that would not be fully captured in standard (four-digit NAICS) factor content calculations because of aggregation bias. Krugman concludes that "the rapid rise in manufactures imports from developing countries probably is, indeed, a force for growing inequality," although the available data are not up to the task of quantifying this effect given the "increasingly finegrained nature of international specialization and trade."

But Krugman's numerical example and intuition suggest that the distributional impact of increased trade from the vertical fragmentation of production between North and South is likely to be substantially less than proportional to the growth in the volume of trade (particularly of imports from the South as a share of the North's GDP). If this is the case, then the two existing approaches to estimating trade impacts-the Krugman 1995 aggregate "but for" analysis in which the distribution impacts of NorthSouth trade are essentially proportional to the import share, ${ }^{3}$ and the micro factor content studies, such as those by George Borjas, Richard Freeman, and Katz and by Robert Lawrence ${ }^{4}$ - can provide upper- and lower-bound estimates of the impacts of trade on wage inequality in the North.

3. Paul R. Krugman, "Growing World Trade: Causes and Consequences," BPEA, no. 1 (Spring 1995): 327-77.

4. George J. Borjas, Richard B. Freeman, and Lawrence F. Katz, "How Much Do Immigration and Trade Affect Labor Market Outcomes?" BPEA, no. 1 (1997): 1-90; Lawrence, Blue-Collar Blues. 
Josh Bivens's updating of the Krugman 1995 approach to more recent U.S. data suggests that trade with developing countries served to expand the wages of skilled relative to unskilled workers (the college wage premium) by 6.9 percent (log points) in 2006, compared with 4.8 percent (log points) in $1995 .{ }^{5}$ This upper-bound estimate suggests that increased trade with developing countries could explain a 2.1-log-point expansion of the skill premium from 1995 to 2006, or about 30 percent of the 7-log-point increase in the college wage premium from 1995 to 2006 documented by David Autor, Katz, and Melissa Kearney. ${ }^{6}$ The lower-bound estimate by Lawrence using disaggregate skill factor content analysis suggests that growth in trade with developing countries over the last decade has had essentially zero impact on the skill premium. ${ }^{7}$ My guesstimate using the developing country import share of around 2 percent of U.S. GDP in 1979 is that the Krugman-Bivens upper-bound approach could explain about 4 to $5 \log$ points (or 15 to 19 percent) of the 26-log-point rise in the college wage premium from 1980 to 2006. And the lower-bound micro factor content studies cited by Krugman in table 1, combined with the new Lawrence estimate, suggest a lower bound of a 1.5- to 3-log-point impact of trade with developing countries on the college wage premium from 1980 to 2006, accounting for 6 to 12 percent of its overall rise.

My bottom line is that even taking into account the aggregation biases in traditional factor content calculations due to the vertical fragmentation of production, growing trade with developing countries is still at most a modest contributor to rising U.S. wage inequality since 1980 . The skill content impact of growing international trade appears to be a much smaller contributor to rising U.S. educational wage differentials than the large slowdown in U.S. skill supply growth after 1980 (from 3.9 percent a year for 1960-80 to 2.3 percent a year for 1980-2005), largely arising from slower growth in educational attainment of successive U.S. birth cohorts. ${ }^{8}$

PUZZLES FOR TRADE-BASED EXPLANATIONS OF RISING U.S. WAGE INEQUALITY. Several empirical patterns appear difficult to reconcile with the view that growing international trade is the driving force behind rising U.S.

5. L. Josh Bivens, "Globalization and American Wages: Today and Tomorrow," EPI Briefing Paper 196 (Washington: Economic Policy Institute, October 2007).

6. David H. Autor, Lawrence F. Katz, and Melissa S. Kearney, "Trends in U.S. Wage Inequality: Revising the Revisionists," Review of Economics and Statistics 90 (May 2008): 300-23.

7. See Lawrence, Blue-Collar Blues.

8. Claudia Goldin and Lawrence F. Katz, "Long-Run Changes in the Wage Structure: Narrowing, Widening, Polarizing," BPEA, no. 2 (2007), 135-65; Goldin and Katz, The Race between Education and Technology (Harvard University Press, 2008). 
wage inequality through Stolper-Samuelson effects. First, the standard Heckscher-Ohlin trade model implies that every U.S. sector should become less skill intensive as increased international integration increases the wages of skilled relative to unskilled workers. In fact, within-sector skill upgrading has been widely documented in almost all U.S. industries in recent decades. ${ }^{9}$ Krugman's modified model does provide one resolution of this puzzle, in that the outsourcing of less skilled tasks in each sector could lead to observed within-sector skill upgrading in traded goods sectors. But the similar patterns of skill upgrading in largely nontraded goods and services sectors strongly suggest that skill-biased technological change has been a stronger force than Stolper-Samuelson-type effects on U.S. relative skill demands.

On the other hand, Krugman's extension of the standard trade model does not really help one understand rising wage inequality in the South with growing trade. ${ }^{10}$ Furthermore, it is not clear that one needs any acceleration in demand for more-skilled workers in the United States arising from factors related to globalization to explain rising U.S. skill differentials, given the sharp slowdown in the growth of U.S. skill supply.

SOME FURTHER ISSUES. Krugman's fascinating paper should motivate further work toward a better understand of recent changes in the nature of international trade and supply chains, and how such changes affect the U.S. labor market. Following the approach of Borjas, Freeman, and Katz, one might be able to make further progress in micro factor content studies by using historical information on U.S. factor ratios by industry, taken from periods before imports from developing countries surged and international supply chains fragmented. U.S. domestic skill shares in an industry from twenty years or so ago may provide a useful upper-bound estimate of the unskilled labor that would be necessary to replace imports from developing countries within detailed sectors. Additionally, some updating of the cross-industry studies that used data through the 1990s (such as that by Autor, Katz, and Alan Krueger ${ }^{11}$ ) on the relative importance of trade factors (import shares and outsourcing measure) versus indicators of techno-

9. Robert Z. Lawrence and Matthew Slaughter, "International Trade and American Wages in the 1980s: Giant Sucking Sound or Small Hiccup?" BPEA: Microeconomics, no. 2 (1993): 161-226; David H. Autor, Lawrence F. Katz, and Alan B. Krueger, "Computing Inequality: Have Computers Changed the Labor Market?" Quarterly Journal of Economics 113 (November 1998): 1169-1213.

10. Pinelopi Goldberg and Nina Pavcnik, "Distributional Effects of Globalization in Developing Countries," Journal of Economic Literature 45 (March 2007): 39-82.

11. Autor, Katz, and Krueger, "Computing Inequality." 
logical change would also be useful in gaining a better empirical understanding of how recent globalization is affecting U.S. skill demands.

Although Krugman takes seriously the increasingly complex nature of supply chains and international trade flows, he does not show similar sophistication in this paper in his treatment of labor market data and wage inequality trends. Krugman's model focuses on a single unskilled-skilled wage differential, and he plots the college wage premium and the 90-50 $\log$ wage differentials in his figure 8 . But U.S. wage structure trends differ between the early globalization (traditional trade) era of the 1980s, in which the wage structure widened in a monotonic fashion, and the last two decades (the vertical fragmentation era), in which wage inequality continued expanding in the top half of the distribution but stopped growing in the bottom half. Furthermore, the returns to education have increasingly convexified since the late 1980s, with the four-year college premium growing modestly and the postcollege (graduate) premium continuing to rise rapidly. Within-group wage inequality has grown rapidly for collegeeducated workers and almost stopped growing for non-college-educated workers. ${ }^{12}$

A key question that future work should address is whether international trade and outsourcing can help one understand the changing nature of rising U.S. wage inequality as manifested in the increasing polarization of U.S. employment into high- and low-wage jobs at the expense of middlewage jobs. Models of computerization that take into account how computers are actually used go some distance toward understanding these patterns, showing that computers are complementary to high-skilled workers with abstract skills, substitute for the routine tasks of middle-skilled workers, and do not substantially affect the in-person tasks of many lowerskilled workers. ${ }^{13}$ My sense is that the growing vertical fragmentation of production across North and South emphasized by Krugman is likely to lead increasingly to outsourcing of many of the tasks of middle-skilled workers (production jobs in the upper half of the noncollege wage distribution, middle management jobs in the lower half of the college distribution). Trade models incorporating more than two skill groups and both withinand between-group wage inequality will be necessary to make further progress on these issues.

12. Autor, Katz, and Kearney, "Trends in U.S. Wage Inequality"; Goldin and Katz, "Long-Run Changes in the Wage Structure."

13. David H. Autor, Frank Levy, and Richard Murnane, "The Skill Content of Recent Technological Change: An Empirical Investigation," Quarterly Journal of Economics 118 (November 2003): 1279-1333; Autor, Katz, and Kearney, "Trends in U.S. Wage Inequality." 
One also needs to consider how labor market institutions in the North might mediate the impact of globalization on the wage structure. If the jobs for less skilled workers in the traded goods sectors that get displaced by imports tend to be unionized or earn efficiency wage premiums, then the distributional consequences of increased trade with developing countries may be larger than suggested by standard models that assume competitive labor markets. ${ }^{14}$ Previous research suggested that the loss due to trade of jobs paying high economic rents was only a modest factor in rising U.S. wage inequality through the early $1990 \mathrm{~s},{ }^{15}$ but it would be nice to see a further consideration of these factors using more recent data.

Finally, also missing from Krugman's analysis is the difference in the consumption baskets of high- and low-skilled workers (or high- and lowincome consumers) arising from nonhomothetic preferences. Increased imports from developing countries (especially China) seem to particularly reduce prices for the "lower-quality" nondurable goods that make up a larger share of the consumption basket of lower-income U.S. families. ${ }^{16}$ Such skill nonneutralities in the consumption impacts of growing trade with developing countries imply that the welfare effects of increased trade for different skill groups may differ from the standard relative wage impacts.

\section{COMMENT BY}

ROBERT Z. LAWRENCE At several points in this paper Paul Krugman is critical of my recent book on the topic of trade and inequality, ${ }^{1}$ so I appreciate the opportunity the editors have given me to comment on his paper. Independently, Krugman and I both began studying this question with similar priors, expecting to find that over the past decade trade had become a much more important contributor to wage inequality. But we have come out in different places, because we disagree about how much increased wage inequality there has actually been and what kinds of models best capture what is happening.

14. Lawrence F. Katz and Lawrence H. Summers, "Industry Rents: Evidence and Implications," BPEA: Microeconomics (1989): 209-90.

15. George J. Borjas and Valerie A. Ramey, "Foreign Competition, Market Power, and Wage Inequality," Quarterly Journal of Economics 110 (November 1995): 1075-1110.

16. Christian Broda and John Romalis, "Inequality and Prices: Does China Benefit the Poor in America?" (University of Chicago Graduate School of Business, March 2008).

1. Robert Z. Lawrence, Blue-Collar Blues: Is Trade to Blame for Rising US Income Inequality? (Washington: Peterson Institute for International Economics, 2008). 
In the 1980s, growing wage inequality was pervasive and obvious. Although the measures differed in magnitude, evidence of increased wage inequality emerged whether workers were distinguished by education, occupation, or experience; whether the data were for women or men; and whether the focus was on the lower or the upper half of the wage distribution. The pervasive nature of this rising inequality suggested that powerful forces were at work and provided support for relatively straightforward explanations that entailed some amalgam of causes, such as a shift in social norms, skill-biased technological change (due to the adoption of computers), immigration, and Stolper-Samuelson effects associated with expanding trade.

In addition, it was possible to find marked differences, at the levels of aggregation permitted by the input-output tables, between the net skill intensity of imports and the skill intensity of goods produced in the domestic economy. This combination of growing inequality and an increase in the relative supply of unskilled labor embodied in imports led naturally to measuring the partial contribution of trade to increased wage inequality using factor content and "warranted" price methodologies. It also justified simulations using simple two-factor models such as that used by Krugman in his earlier Brookings Paper. ${ }^{2}$

In the 1990s, however, despite the rapid growth of imports from developing countries, the wage inequality story has become much more complicated. Krugman leaves the impression that wage inequality has continued apace and dismisses evidence to the contrary. For example, he points to an increase in the 90-50 ratio and the rising college premium for men over the 1990s, and he dismisses the absence of a growing college premium more recently as a cyclical development. But his use of data is selective, and he ignores the key point that there is no longer evidence of growing wage inequality that supports a simple story of pervasive and growing differences in the rewards to skill.

At least three considerations complicate the current wage picture. First, since the early 1990s, the wages of the least skilled Americans-the lowest 10 percent - have more than kept pace with those in the middle, and high school dropouts have seen faster wage growth than those who complete high school but do not attend college. This is a really important development for those concerned about immigration as well as trade and has led labor economists such as David Autor, Lawrence Katz, and Melissa Kearney to develop

2. Paul R. Krugman, "Growing World Trade: Causes and Consequences." BPEA, no. 1 (Spring 1995): 327-77. 
more complicated models of technological change. ${ }^{3}$ Second, since the mid1990s there has been almost no increase in the college-high school premium for women. According to estimates by the Economic Policy Institute (EPI), for example, the 47.1 percent premium in 2005 was barely above the premium of 46.7 in $1995 .{ }^{4}$ Third, the EPI estimates also show that between 1999 and 2005, even for men, the increase in the college-high school premium was very small, at only 1.5 percentage points. Similarly, between December 1999 and December 2006, as measured by the employment cost index, which includes both wages and benefits, nominal compensation of workers in white-collar occupations has grown by the exactly the same amount-25 log points-as for those in blue-collar occupations. Workers in the category of "executive, administrative, and managerial occupations," for example, have experienced in relative terms the same increases in compensation as "machine operators and handlers." Roughly equal compensation growth is also evident when compensation is classified by sector (manufacturing versus services) or by union membership versus nonmembership. ${ }^{6}$ All of these data call into question the idea that inequality has continued to grow between workers with different levels of skill.

Krugman observes that since there may have been other offsetting factors, even if there has been no overall increase in wage inequality, it does not necessarily prove that trade has had no effect. That is true. Nonetheless, if other factors are improving the relative wages of unskilled workers, then trade (or immigration) is less of a problem for them. And the ex post data still warrant the conclusion that any negative effects from trade have been too small to dominate the outcome.

But it could also be the case that expanding trade with developing countries does not necessarily lead to increased wage inequality between skilled and unskilled workers. Indeed, it could be that as the economy has adjusted to trade with developing countries, the incremental effects on inequality have diminished. There are several reasons why this might be so.

3. David H. Autor, Lawrence F. Katz, and Melissa S. Kearney, "The Polarization of the U.S. Labor Market." Working Paper 11986 (Cambridge, Mass.: National Bureau of Economic Research, 1996).

4. See Lawrence Mishel, Jared Bernstein, and Sylvia Allegretto, The State of Working America 2006/2007 (Cornell University Press and Economic Policy Institute, 2007), p. 145. The data used for their figure $3 \mathrm{M}$ are available at www.epi.org/content.cfm/datazone dznational.

5. The latter group comprises "machine operators, assemblers, and inspectors occupations" and "handlers, equipment cleaners, helpers and laborers occupations."

6. See Lawrence, Blue-Collar Blues, pp. 29 and 30. 
The most obvious is complete specialization. A significant share of American imports today may no longer have domestically produced counterparts. Even if classified under the same heading, imports could differ substantially from domestically produced goods, and this could be true of both intermediate inputs and final goods. This would mean that although the declining prices of these goods that Krugman points to yield benefits to buyers, they should not be expected to change relative wages or even to cause the dislocation of U.S. workers.

To be sure, the proportion of goods that are fully replaced by imports could increase over time, but as the process advances, the marginal effects on inequality should be expected to diminish. Given different factor prices in the United States and the developing world, it is likely that the first goods to be fully replaced by imports would be the most unskilled labor intensive. As the process of specialization expands, however, the goods that are replaced would be increasingly less intensive in their use of unskilled labor. Since smaller proportions of unskilled labor would be displaced, the amount of wage inequality caused for each dollar of additional replacement would decline. Thus, paradoxically, the further the process of specialization advances, the smaller its marginal impact on inequality.

Similar arguments could be made in the case of offshoring of intermediate goods. The model that Krugman develops in the paper predicts, correctly, that inequality would increase as the adjustment takes place. But once a particular offshoring process has moved abroad, one would not expect further increases in U.S. inequality. Again, as with finished goods, one might expect the most unskilled labor-intensive processes to have been offshored first and, at the margin, for offshoring to cause diminishing amounts of inequality.

A second possibility is that there have been "factor intensity reversals" in what were once relatively unskilled labor-intensive industries. U.S. firms have increasingly adopted skill-intensive methods of production and more automation to compete against goods made abroad with less skilled labor. Indeed, several of the earlier studies of wage behavior took note of the rising ratio of nonproduction to production workers throughout U.S. manufacturing, a development that was at odds with the simple StolperSamuelson story. This development would mean that if imports cause displacement, they do not disproportionately displace unskilled workers.

A third possibility is that the developing countries have upgraded the skill intensity of their exports. This could occur either because their workers have become more sophisticated and skilled, or because some of the goods to which they add unskilled labor contain a significant amount of value that 
has been added by skilled labor in developed countries. Thus, a machine coming from China could be 75 percent Japanese and compete with a machine produced in the United States with relatively skilled workers.

In sum, U.S. trade today combines these elements in proportions that are hard to disentangle in a manner that allows for a sufficiently precise matching of products and the wages earned in producing them. At relatively high levels of aggregation, the data can be interpreted to indicate that manufactured imports overall, and even those from developing countries such as China, are concentrated in U.S. manufacturing sectors that pay wages significantly higher than the U.S. average. This evidence, which is compatible with the factor reversals and upgrading stories, suggests that import displacement does not fall disproportionately on less skilled workers.

At more disaggregated levels, however, the data suggest that goods imported from developing countries such as China are associated with relatively less skilled labor inputs, which would be support for the traditional story. ${ }^{7}$ But there is also evidence, based on unit values, that suggests that these goods are qualitatively different from those produced by developed countries such as the United States. This provides support for the view that some of this trade reflects more complete specialization, and as such does not result in either wage inequality or downward pressure on wages generally.

All told, therefore, there is some support for the view that these mitigating effects are operating, and they give reasons to doubt that declining import prices or rising import volumes from developing countries automatically generate increasing wage inequality in the United States. Moreover, the most striking feature of U.S. wage behavior since 2000 is not growing inequality but rather that wage gains by both workers with only a high school diploma and workers with a college degree have been meager at best.

GENERAL DISCUSSION Lawrence Katz noted that in micro data using the employment cost index, inequality has stopped increasing in the bottom half of the income distribution but continues to grow in the top half. Incomes in the top 20 percent of the distribution are still rising relative to everyone else, and those in the middle of the distribution are not; including benefits in the calculation thus does not change the result. Alan Krueger observed that since the mid-1990s the bottom decile of the income distri- 
bution has done relatively well. He wondered how to explain this, as one would assume that the price shocks that followed the currency crises of the 1990s would have disproportionately hurt those at the bottom. He wondered whether trade simply affects the middle of the distribution more than the bottom, or whether some other factor is at play.

Robert Gordon pointed out that changes in U.S. wage inequality are unlikely to be explained by any one factor alone, especially trade. For example, much of the increase in inequality is the result of rapid income growth in the top 1 percent of the distribution. CEOs are now paid 300 to 400 times what the average production worker is paid, and this does not seem to be due to trade. Likewise, over the last twenty years, the average real wage of a major league baseball player has increased by 9 percent a year, which certainly has nothing to do with trade. This argues for considering multiple explanations.

Robert Hall found it unsurprising that incomes at the top end of the distribution are growing so quickly, given the high returns to intellectual property in today's economy. For example, if the wholesale price of an iPod is, say, $\$ 250$, the labor component might well be only $\$ 20$, of which only $\$ 5$ is unskilled. That means the remaining $\$ 230$ is a return to intellectual property.

Martin Baily noted that many of the effects under discussion are very small. For example, services imports from India are 0.05 percent of GDP. Likewise, the 14 million workers in manufacturing make up a small fraction of total employment. Listening to media accounts, one might get the impression that Wal-Mart imports all of its inventory from China. In fact, the figure was only 10 percent in 2004. It is important to put these trends in perspective.

Alberto Alesina emphasized the importance of understanding what share of inequality growth is explained by trade. He rejected the view that this number is irrelevant because society will choose to redistribute a certain amount to the poor regardless of the cause of their poverty. On the contrary, if trade is causing the growth in inequality, there will be much greater political pressure to restrict trade than if rising inequality were due to some other cause. From this political economy perspective, accurately quantifying the effects of trade on inequality is crucial.

Lawrence Summers wondered whether it would be useful to examine differences in the effects of trade in different parts of the country. The fortunes of some regions, particularly the Midwest, seem more closely linked to international competition than others. 